\title{
A multi-component flood risk assessment in the Maresme coast (NW Mediterranean)
}

\author{
Caridad Ballesteros $^{1} \cdot$ José A. Jiménez $^{1} \cdot$ Christophe Viavattene $^{2}$
}

Received: 25 February 2017/Accepted: 4 September 2017/Published online: 18 September 2017

(C) The Author(s) 2017. This article is an open access publication

\begin{abstract}
Coastal regions are the areas most threatened by natural hazards, with floods being the most frequent and significant threat in terms of their induced impacts, and therefore, any management scheme requires their evaluation. In coastal areas, flooding is a hazard associated with various processes acting at different scales: coastal storms, flash floods, and sea level rise (SLR). In order to address the problem as a whole, this study presents a methodology to undertake a preliminary integrated risk assessment that determines the magnitude of the different flood processes (flash flood, marine storm, SLR) and their associated consequences, taking into account their temporal and spatial scales. The risk is quantified using specific indicators to assess the magnitude of the hazard (for each component) and the consequences in a common scale. This allows for a robust comparison of the spatial risk distribution along the coast in order to identify both the areas at greatest risk and the risk components that have the greatest impact. This methodology is applied on the Maresme coast (NW Mediterranean, Spain), which can be considered representative of developed areas of the Spanish Mediterranean coast. The results obtained characterise this coastline as an area of relatively low overall risk, although some hot spots have been identified with high-risk values, with flash flooding being the principal risk process.
\end{abstract}

Keywords Flood · Storms · Flash floods $\cdot$ SLR · Risk · Indicators · SPRC

Caridad Ballesteros

caridad.ballesteros@upc.edu

José A. Jiménez

jose.jimenez@upc.edu

Christophe Viavattene

C.Viavattene@mdx.ac.uk

1 Laboratori d'Enginyeria Marítima, Universitat Politècnica de Catalunya Barcelona Tech, c/Jordi Girona 1-3, Campus Nord ed D1, 08034 Barcelona, Spain

2 Flood Hazard Research Centre, Middlesex University, The Burroughs, Hendon, London NW4 4BT, UK 


\section{Introduction}

Coastal regions are the areas most threatened by natural hazards (EEA 2006; Kron 2013). These areas contain a large number of receptors (natural, physical, and socio-economic) (EEA 2013a), making them particularly vulnerable. Floods, in particular, are considered to be one of the most harmful phenomena, causing $69 \%$ of the overall natural catastrophic losses in Europe (CEA 2007; Llasat 2009). In Spain, the Consorcio de Compensacion de Seguros (CCS), a public corporation which provides insurance to cover "extraordinary" risks, states that $61 \%$ of its resources are required to mitigate damages incurred as a result of flood events (Insurance Compensation Consortium 2016). The greatest number of casualties and material damages have occurred in the Spanish Mediterranean (Barnolas and Llasat 2007; Camarasa-Belmonte and Soriano-García 2012). Moreover, in the absence of additional adaptation, the risk from coastal flooding is predicted to rise in the future as a result of two primary factors. First, climate change and rising sea levels are expected to increase the frequency and severity of flood events (EEA 2013b), and second, the number of potentially exposed receptors (infrastructure, socio-economic assets, population) is increasing in floodplains and/or near the sea (e.g. Hallegatte et al. 2013).

Flood risk can be defined as the product of the probability of flooding and the associated negative consequences or damages (UNISDR 2009). In order to reduce the negative consequences of flooding, it is necessary to consider the hazard, the exposure, and vulnerability values potentially affected. Traditionally, flood risk in coastal areas has been managed with the use of physical structures to protect against floods (e.g. see Saurí-Pujol et al. 2001). However, it is recognised that absolute protection is both unachievable and unsustainable due to the high costs and inherent uncertainties (Schanze 2006). As a result, there has been a shift in environmental policy in the European Union from emphasis on flood protection to flood risk management. The European Directive 2007/60/EC (EC 2007) urges flood risk analysis and flood risk management at the community level, based on local circumstances and the types of floods (river floods, flash floods, urban floods, and flooding from the sea in coastal areas) which may be present.

To correctly define coastal management policies for successful flood risk management, given the spatial and temporal nature of flood risk, broad-scale integrated assessments are essential (Dawson et al. 2009; de Moel et al. 2015). Thus, in order to manage the coastal zone at a regional scale, a holistic approach is required where, in addition to the factors determining flood risk (hazards and consequences), the various flood processes acting at different temporal scales should be considered.

In Mediterranean coastal regions, floods can be present as a result of forcing from multiple origins acting at different timescales. Flooding from a marine origin (related to changing sea level) can be the result of a marine storm associated with a short-term scale (Benavente et al. 2006; Anselme et al. 2011; Bosom and Jiménez 2011). Regarding flooding from the same source, but associated with a long-term scale, the effect of climate change can cause a permanent inundation due to SLR (Nicholls et al. 1999). Finally, regarding flooding of a terrestrial source, and caused by short-term convective rainfall at the mouth of stream systems, floods in the Mediterranean coast can be present in the form of flash floods (Llasat et al. 2010a, b; Tarolli et al. 2012).

In order to manage coastal flood risk and to develop measures for effective and longterm disaster risk reduction, it is therefore necessary to know not only the magnitude of each of the different flood components (flash flood, marine storm, SLR) and their associated consequences, but also their relative importance in relation to one another. This input is essential when analyses at a regional scale are taken into account (Bryan et al. 
2001; De Pippo et al. 2008; Vinchon et al. 2009), as it allows coastal managers to identify and detect the most critical areas at risk as a result of the different flood components. This analysis then enables a more detailed assessment to be undertaken and for resources to be focused in these specific locations.

Although established approaches exist to carry out a comprehensive analysis and assessment of flood risk for each individual flood component, few studies address all components combined together (Kappes et al. 2012). Doing so presents particular challenges due to the difficulty of analysing multiple components (processes) acting at different spatial and temporal scales. In order to tackle this problem, different methodologies have been developed by means of indicators (e.g. Gornitz 1990; McLaughlin et al. 2002; Birkmann 2007; Wang et al. 2011; Balica et al. 2012; Creach et al. 2015). Through the use of indicators, it is possible to integrate risk components with homogenous units and to integrate multiple-flood hazards into one flood risk assessment. One advantage of this approach is that it allows an evaluation of all components and their associated risks using methods that do not require extensive data or a high degree of model accuracy.

Here, a methodology framed within the Source-Pathway-Receptor-Consequence (SPRC) model is presented in order to determine the potential flood risk as a result of different flood components. The methodology uses representative indicators that are suitable when comparing flood risk between different locations and also between flood types. Within this context, the main aim of this work is to introduce a framework to analyse coastal flood risk as a result of multiple components (flash flood, marine flooding, SLR) at the regional scale. The practical objective is to identify the most sensitive areas to flooding and to verify the most relevant flood component in terms of magnitude and potential for damage. With this information, coastal managers can prioritise their efforts in areas where risk management is needed the most.

This approach is applied in the Maresme (NW Mediterranean, Spain) as a paradigm of a developed coast where significant settlement and infrastructure development, coupled with intensive tourism, make the impacts of natural hazards very high (Barnolas and Llasat 2007; Llasat et al. 2010a, b; Jiménez et al. 2012).

\section{Study area and data}

\subsection{Study area}

On the Catalan coast (NW Mediterranean), north of the city of Barcelona, the Maresme region comprises $45 \mathrm{~km}$ of long, straight beaches (Fig. 1). Along the coastline, the existence of five marinas, combined with a net longshore sediment transport pattern directed southwards, has led to a disruption of sediment movement, increasing beach volume updrift and starving down-drift beaches (Jiménez et al. 2012). In the Maresme coastal zone, another relevant geomorphological feature is the presence of ephemeral dry streams. These are characterised by a short and steep slope, which, after an intensive rainfall typical of the Mediterranean regions, may cause immediate high-energy water run-off towards the sea. This is mainly due to the complex orography with the Littoral range parallel to the coast which plays an important role in rainfall and flood production (Barnolas and Llasat 2007). The precipitation regime is characterised by a yearly distribution, with two maximum peaks in autumn and spring (Barnolas and Llasat 2007). However, high rainfall 


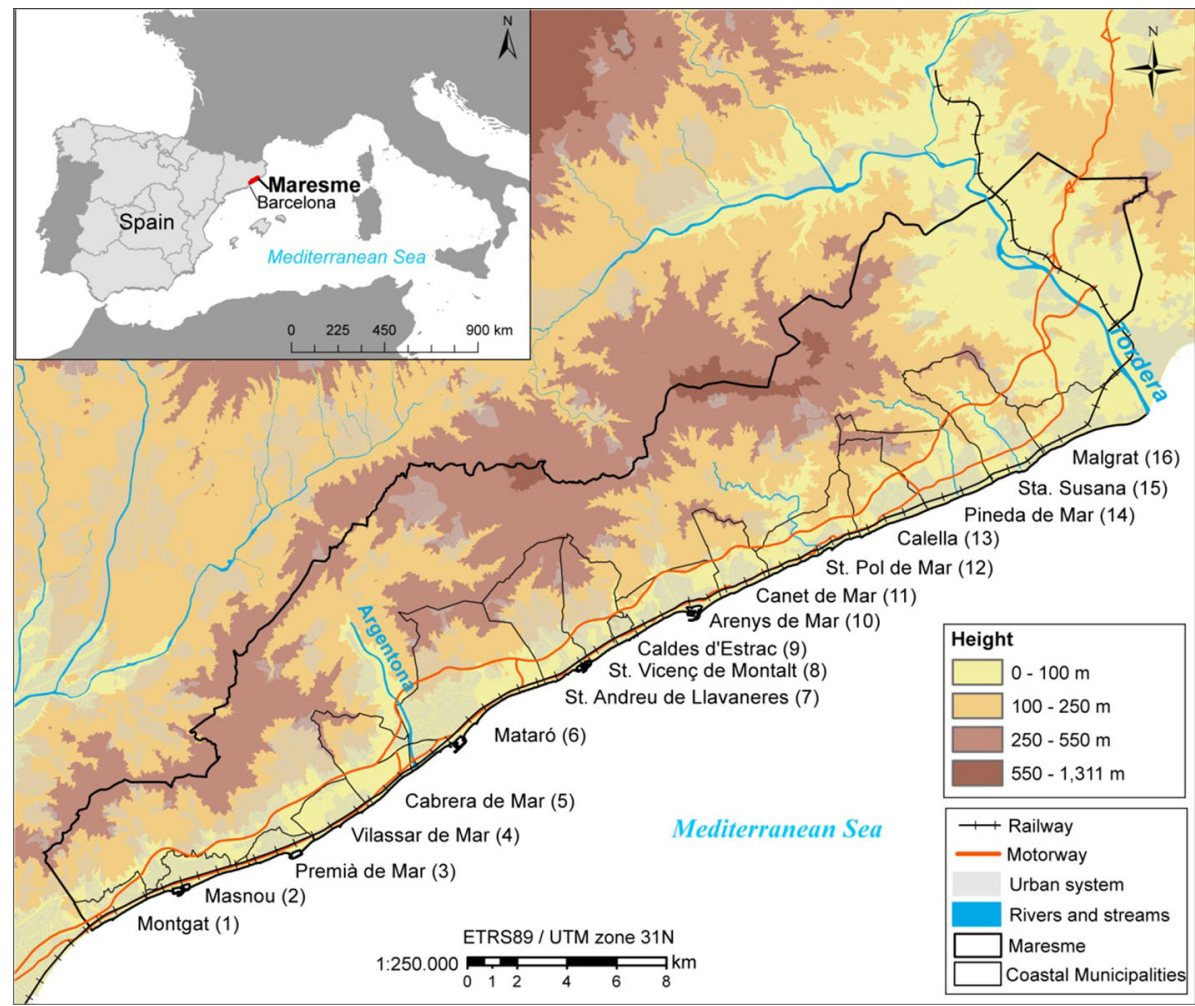

Fig. 1 Study area

precipitation produced by convective events shows only one peak between the end of summer and autumn (Llasat 2009).

From an administrative standpoint, the coast is comprised of 16 coastal municipalities, which represent the most densely populated areas of the region. Seventy five percentage of the population of the Maresme region, around 331,000 inhabitants, are concentrated in coastal municipalities which represent $31 \%$ of the total territory (IDESCAT 2014). The socio-economic development has been based mainly on the service sector, although the proximity to different urban areas and transport routes has led to the distinction of subregions that reflect different territorial dynamics. Thus, the southern municipalities near Barcelona have focused on residential development, while the northern municipalities have based their economies on tourism.

The strong urban and infrastructure development, coupled with economic activities which are dependent on the coastal zone, make the region particularly vulnerable to the direct effects of flood events (Barnolas and Llasat 2007; Llasat et al. 2010a, b; Jiménez et al. 2012) and also to the indirect impacts of economic activities such as tourism. Indeed, some roads and the coastal railway have been built within the normally dry, river basins. Furthermore, due to the proximity of the railway to the sea, rail services have been affected on many occasions by wave overtopping. 


\subsection{Data}

In order to determinate risk, information is required for both the forcing-induced hazards and exposure values (receptors).

To characterise marine flooding, wave and water levels were taken from the hindcast SIMAR-44 database, which was generated from high-resolution modelling of the atmosphere, sea level, and waves carried out by Puertos del Estado within the HIPOCAS project (Guedes-Soares et al. 2002; Ratsimandresy et al. 2008). Data used cover the period from 1 January 1958 to 31 December 2001 as time series of meteorological tide levels, deepwater significant wave height $\mathrm{H}_{\mathrm{m} 0}$, mean period $T_{\mathrm{m}}$, peak period $T_{\mathrm{p}}$, and the mean wave direction every $3 \mathrm{~h}$. Following previous work by Bosom and Jiménez (2011), who analysed the spatial homogeneity of the wave climate in the study area, wave conditions were selected from one single location for the entire region.

In order to characterise flash floods, the annual maximum daily precipitation for a return period of 10 years (INM 2007) was selected in this work as representative of an extreme precipitation. This information yields $2.5 \times 2.5 \mathrm{~km}$-sized cells for all of Catalonia.

Finally, to characterise the sea level rise due to climate change, two climatic scenarios have been considered: scenario RCP 8.5 as presented within the last AR5 report (IPCC 2015), and the high-end scenario (a rise of $2 \mathrm{~m}$ ) as the worst case and relevant for coastal management (e.g. Hinkel et al. 2015).

To measure the surface topography, and thus coastal slope, a digital elevation model of $5 \times 5$ m cell size (ICGC 2015) was used. Moreover, to determine physical-geomorphological features in the assessment of flash flood risk, information on the Maximum Green Vegetation Fraction by the USGS Land Cover Institute (Broxton et al. 2014) is used to describe the abundance of vegetation, and the Soil Texture developed by the European Soil Data Centre (EC 2015) with an spatial resolution of $1 \times 1 \mathrm{~km}$ cell size has been used.

To assess the consequences and to accurately identify receptor exposure, a detailed land-use map in vector format developed by the Ecological and Forestry Applications Research Centre (CREAF) was used (Ibàñez and Burriel 2010). This map was obtained by means of a photo-interpretation analysis of aerial photographs with a scale of 1:2500 and $0.25 \mathrm{~m}$ pixel resolution. In addition to the land use, a large number of socio-economic factors have been considered with information provided by the Statistical Institute of Catalonia (IDESCAT 2014).

\section{Methodology}

\subsection{SPRC model}

The basic conceptual framework used to gather all of the different components involved in coastal flood risk is the well-established Source-Pathway-Receptor-Consequence model (Fig. 2). This model was first used in natural science to describe the movement of a pollutant from a source though a conducting pathway to a potential receptor (Holdgate 1979). Later, this conceptual model was adapted for the modelling of coastal flooding (Evans et al. 2004; Gouldby and Samuels 2005) as it can easily describe a floodplain in terms of the process of flood risk propagation (Narayan et al. 2014).

In the present application of the SPRC, coastal flood risk is presented as the result of different forcings (sources) that cause flood processes at different spatial and temporal 


\section{Source $\longrightarrow$ Pathway $\longrightarrow$ Receptor $\longrightarrow$ Consequences}

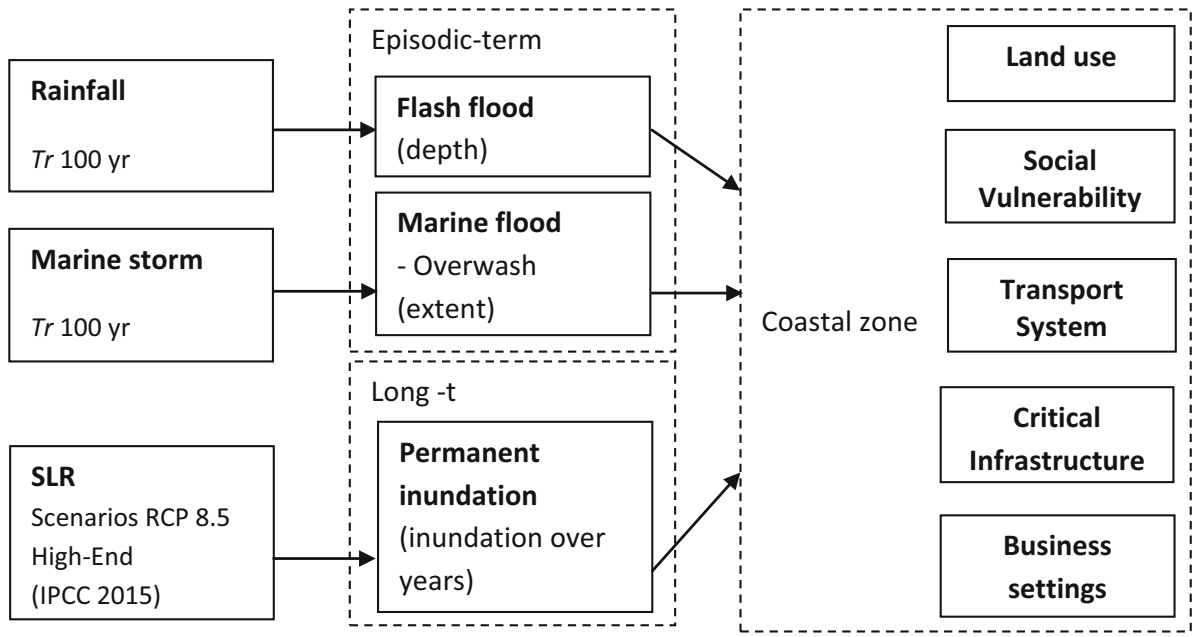

Fig. 2 SPRC model for coastal flood risk assessment

scales (pathways) with an associated impact for the exposure values and consequences (Fig. 2).

Three main flood processes are here considered as: flash floods, marine floods, and inundation by SLR. Flash floods and marine floods are characterised as episodic events associated with hydro-meteorological, acute, and ephemeral phenomena (the inundation is transient) that are expressed in probabilistic terms. In contrast, SLR is characterised as a long-term process which causes a permanent inundation of the affected area. In this case, the forcing is characterised as the evolution over time of the sea level for different scenarios.

To characterise the receptor (the coast) and the associated flood consequences, a major number of socio-economic coastal values are considered. Hence, the consequences are the resulting value of the integration of the following five components: land use, social vulnerability, transport system, critical infrastructures, and economic activity.

\subsection{Flood risk assessment}

In order to assess the flood risk associated with each component, an indicator-based approach has been adopted in which the different flood components are evaluated in terms of hazard and exposure indicators across the territory. The components are combined into an absolute flood risk $R_{\text {abs }}$, which is given by:

$$
R_{\mathrm{abs}}=\sum_{j}^{n}\left(\mathrm{HI}_{j} * E_{j}\right)^{1 / 2} * S_{j}
$$

where $\mathrm{HI}$ is the hazard intensity indicator, $E$ is the indicator measuring exposure values, $S$ is the affected area by the analysed flood component, and $j$ is each of the $n$ areas in which the coast is segmented for the assessment. 
Since variables contributing to hazard and exposure are measured in different units, they have been standardised to facilitate their mathematical combination. This standardisation does not affect the main objective of the analysis, i.e. to identify the most sensitive areas along the coast and to compare the contribution of each component. Following previous works (Gornitz 1990; McLaughlin and Cooper 2010; Viavattene et al. 2015), a 1-5 scale has been selected with 1 indicating the lowest contribution to risk (hazard and exposure).

To analyse the risk along the coast at regional scale from the management standpoint, the flood risk indicator is integrated in each municipality, which is the lowest administrative entity. In addition, a municipality-averaged risk value was obtained to characterise the relative importance of the risk along the coast without considering the extension of the flooding area within the municipality. The average risk, $R_{\text {aver }}$, is given by:

$$
R_{\mathrm{aver}}=\frac{\sum_{j}^{n}\left(\mathrm{HI}_{j} * E_{j}\right)^{1 / 2} * S_{j}}{\sum_{j}^{n} S_{j}}
$$

In the following sections, the rationale for the ranking of each component is summarised.

\subsection{Flood hazard assessment}

Hazard assessment can be defined as the process which enables an understanding of the characteristics, nature, and magnitude of the considered threat. In the simplest case, a flood hazard can be characterised as a land surface covered by water. However, as was presented previously, the different flood hazards that were considered differ widely in their characteristics in relation to their physical processes and temporal and spatial scales. Thus, the flooded area associated with episodic components (storms) is temporarily inundated, being a quasi-instantaneous process (the duration of the event), whilst in the case of the longterm component, the affected area is permanently flooded, being a very slow and continuous process.

Flood hazard components associated with stochastic processes are characterised through their extreme probability distributions. Once the probability distribution of the hazard is known, a probability of occurrence is selected which should depend on the objective of the analysis. In this study, following the indications of the EU Floods Directive (EC 2007), a return period $\left(T_{\mathrm{r}}\right)$ of 100 years was selected which can be considered representative of medium-probability events.

In the following sections, the assessment procedure carried out for each component is presented.

\subsubsection{Flash flood}

Flash floods are defined as extreme flood events associated with short, high-intensity rainfalls, mainly of convective origin, that occur locally (Marchi et al. 2010). Extreme events, being greater in magnitude and with a strong seasonality, occur in Mediterranean regions (Sala 2003; Gaume et al. 2009; Llasat et al. 2010a, b; Camarasa-Belmonte and Soriano-García 2012). It is in the coastal areas where these phenomena pose a considerable risk due to the high vulnerability of urban development and an increase in population and tourism during the summer season (Llasat et al. 2010a, b; Camarasa-Belmonte et al. 2011). 
To carry out a flash flood assessment, a two-step approach has been developed. The first step is an analysis of the most susceptible sub-basins affected. Once identified, the second step involves a detailed hazard assessment.

To identify the most susceptible sub-basins, a modified version of the flash flood potential index (FFPI) developed by Smith (2003) has been used. This index combines different physiographic characteristics, which have a strong influence on the hydrologic response of the catchments, and therefore, the potential for flash flooding. The index includes information about the terrain slope $(M)$, land use $(L)$, soil type $(S)$, and vegetation $(V)$. Here, a modified version has been obtained by adding a new factor with information about climatology of extreme precipitation by annual maximum daily rainfall statistics $(R)$ to account for the potential influence of local climatology (Jiménez et al. 2015). Therefore, a territory is not only sensitive to flash flooding due to its geomorphology, but also because it is subjected to a given rainfall regime that may induce such a hazard. The final modified FFPI' index is calculated as follows:

$$
F F P I^{\prime}=\frac{M+L+S+V+R}{5}
$$

To combine these factors, the associated raster data were ranked at the same scale from 1 to 10, considering their hydrologic response as a criteria, as established by Ceru (2012). This index is calculated using raster data so that the territory is completely divided into cells, each with the combined information previously mentioned. In order to identify the highly susceptible sub-basins, this information is integrated by assessing an averaged value of each cell at catchment level (Fig. 3). The resulting values are classified into five

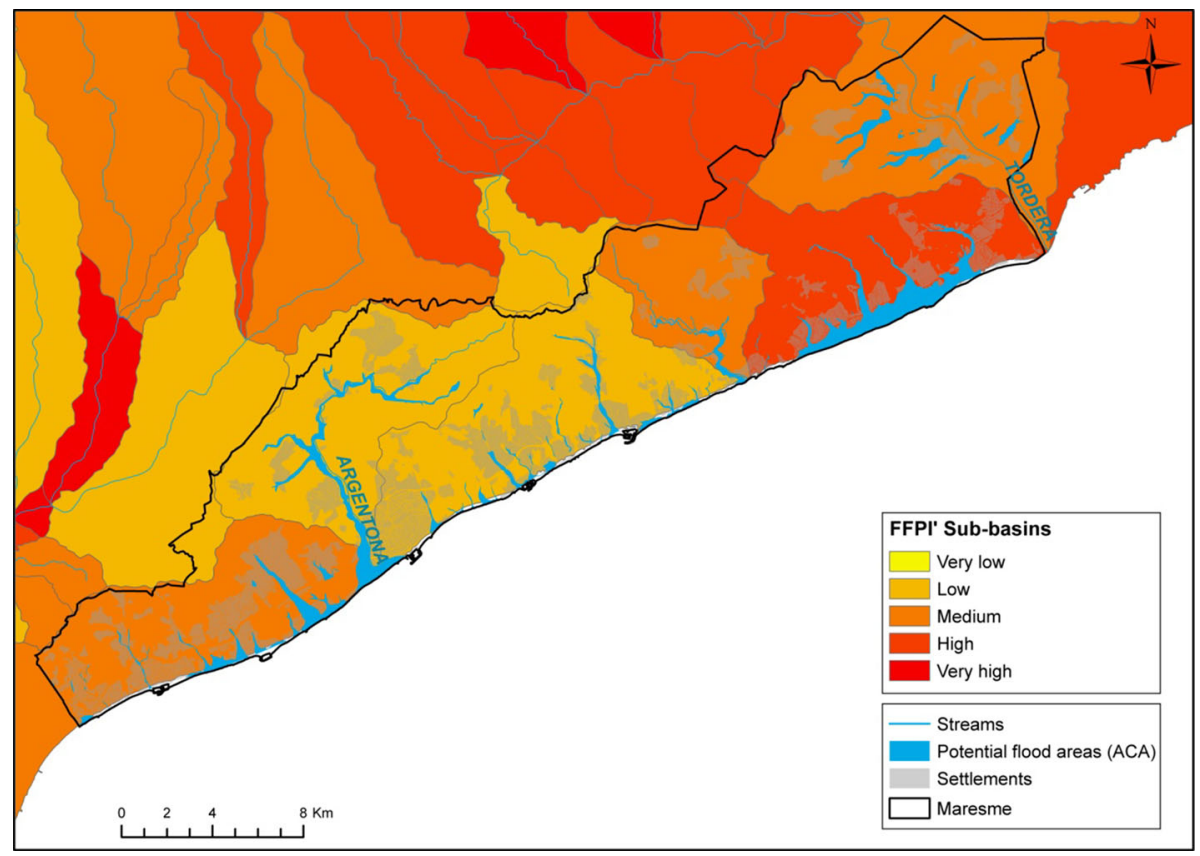

Fig. 3 Flash flood potential index $\left(\mathrm{FFPI}^{\prime}\right)$ in the Maresme region 
categories, which allow for the identification of the most susceptible areas to the effects of flash flooding.

Once susceptible flash flooding areas are identified, a second and more detailed hazard assessment is carried out. To do this, a standard fluvial flood analysis has been conducted. Thus, for a given return period $\left(T_{\mathrm{r}}=100\right.$ years $)$, the flooded area and the flood depth are assessed. In this sense, flood depth is considered a good variable in flood assessment because it is relatively straightforward to link it to direct damages by means of the depthdamage curves.

For the study area, the Catalan Water Agency (ACA) provides information regarding flood depth associated with three return periods, in accordance with the European Floods Directive (2007/60/EC) recommendations. These data have been obtained by means of a hydrologic analysis using the HEC-HMS model and a hydraulic analysis made using the Guad2D model with a detailed digital elevation model (Generalitat de Catalunya 2015).

As mentioned, the flood depth variable can be used to estimate a damage value through the use of depth-damage curves. To establish the hazard intensity scale in five categories, curves proposed by Velasco et al. (2015) have been used which were obtained for the city of Barcelona. From a practical viewpoint, each flooded area, with a given depth interval, is assigned a corresponding hazard intensity value (see Table 1).

\subsubsection{Marine flood}

This component assesses the temporary coastal flood under the influence of marine storms. In this case, the forcing is the temporary increase in mean sea level induced by low atmospheric pressure and onshore winds during the storm resulting in both wave runup and overtopping. The methodology used here has been developed within the RISC-KIT project (see Viavattene et al. 2015; Ferreira et al. 2016).

The hazard intensity along the coast has been evaluated by estimating the water level extreme climate and the extension of the area to be inundated. This was calculated for a total of 46 sectors of $1 \mathrm{~km}$ in length along the coast, where the most representative beach profile was defined for each one. The runup, $\mathrm{Ru}$, as the main water level contributor in the study area (Mendoza and Jiménez 2009) was calculated using the Stockdon et al. (2006) model in beaches and the Pullen et al. (2007) model when the coastline was formed by breakwater. Resultant Ru time series calculated for each profile were then fitted by means of a general pareto distribution (GPD), obtaining a probability distribution for representative beach slopes of the study area.

Table 1 Flood hazards intensity scale

\begin{tabular}{llll}
\hline $\begin{array}{l}\text { Flash flood } \\
\text { Flood depth }(\mathrm{m})\end{array}$ & $\begin{array}{l}\text { Marine flood } \\
\text { Flood extent }(\mathrm{m})\end{array}$ & $\begin{array}{l}\text { SLR-induced inundation } \\
\text { Year when the area will be flooded (year) }\end{array}$ & Hazard intensity \\
\hline$<0.15$ & $\leq 50 \%$ beach width & $>2100$ & 0 \\
$0.15-0.3$ & $\leq 100 \%$ beach width & $2080-2100$ & 1 \\
$0.3-0.5$ & $\leq$ beach width $+20 \mathrm{~m}$ & $2060-2080$ & 2 \\
$0.5-1.0$ & $\leq$ beach width $+40 \mathrm{~m}$ & $2040-2060$ & 3 \\
$1.0-2.0$ & $\leq$ beach width $+60 \mathrm{~m}$ & $2020-2040$ & 4 \\
$>2.0$ & $>$ beach width $+60 \mathrm{~m}$ & 2020 & 5 \\
\hline
\end{tabular}


Given the characteristics of the beach profiles typified by the monotonous increase in elevation landward, and in order to calculate the extension of the area to be inundated, a bathtub approach was applied, assuming that those areas hydraulically connected to the sea and below a certain height were flooded (Poulter and Halpin 2008; Gallien et al. 2011).

Subsequently, flooded areas were classified on a hazard intensity scale based on the reach of the flood extension, considering the characteristics of the beaches in the study area (see Table 1).

\subsubsection{Inundation by sea level rise}

This component assesses coastal flooding due to an increase in sea level in the long term, generally associated with climate change. In contrast to other flood hazards in which the area affected by flooding returns to pre-event conditions following a recovery time, the one caused by SLR is characterised to be a permanent inundation which implies an irreversible land loss.

In this case, the flood component is given by a water level at a given time as a function of a sea level projection. As previously mentioned, two scenarios of sea level projections are used in this study, the IPCC AR5 RCP 8.5 to represent the most likely scenario and a high-end one to represent the high-risk management perspective as a worst-case scenario (see Hinkel et al. 2015). To calculate the inundated area, a GIS-based bathtub approach was adopted in which those areas hydraulically connected to the sea at an altitude lower than a given sea level will be inundated (e.g. Poulter and Halpin 2008; Gallien et al. 2011).

For this component, the criteria to define the hazard intensity have been established based on time. Thus, it is considered that those areas submerged by water for the longest duration will be the most damaged, whereas those submerged by water during a shorter duration will incur less damage. With this assumption, those areas affected first (more time submerged) might not have time (or they will have a shorter time) for adaptation, so damages may be greater, whilst the areas which require more time to be covered by water (less time submerged) will have time to adapt to the changing territory and therefore, future damages could be smaller.

To define the corresponding hazard intensity, a continuous rank is established every 20 years from the present time (2020) to the future (2100). Thus, the flooding area affected first (2020) is assigned a value of five and so on (see Table 1). In this case, as the variable considered is time, the hazard intensity will change as different scenarios are considered. As an example, the area below $+0.5 \mathrm{~m}$ above the mean sea level will have a larger hazard intensity associated under the high-end scenario than under the RCP8.5 one because it will be inundated in a shorter period of time.

\subsection{Consequences}

In the assessment of the consequences, flood damages are usually divided into those caused by direct contact with the receptor and indirect damages triggered by secondary effects, principally with a relationship to the disruption of physical and economic linkages. At the same time, the methods for calculating damages vary depending on whether the damages are tangible, i.e. can be assigned a monetary value, or intangible, not traded in a market (Messner et al. 2007; Green et al. 2011; Meyer et al. 2013; Penning-Rowsell et al. 2013). As the type of receptor varies (properties, people, ecosystems, etc.), the unit of measurement changes, and therefore, many evaluation methods for assessing the consequences exist. 
Within the framework of this work, it is assumed that the consequences can be represented by a set of socio-economic indicators. Following the characterisation of the study area, and bearing in mind the potential direct and indirect consequences of coastal floods, these indicators are represented by the following categories: land use, the social vulnerability of the population, transport systems, critical infrastructure, and business settings. These indicators are evaluated and classified in homogenous units (Table 2) and then combined in a unique exposure value $\left(e_{T}\right)$, using a linear aggregation method as shown below (Viavattene et al. 2015):

$$
e_{T}=\left[\left(e_{\mathrm{LU}} * e_{\mathrm{SV}} * e_{\mathrm{TS}} * e_{\mathrm{CI}} * e_{\mathrm{BS}}\right)\right]^{1 / 5}
$$

To calculate this aggregate value, the exposure values have been characterised in a different way for each type of flood component. In the case of flash flooding and SLRinduced inundation, the exposure values, which in this study are determined by their spatial distribution (i.e. land use, transport system and critical infrastructures), have been evaluated within the flood area, as the spatial extent of the flood is known. Since the hazard intensity of these two components is also spatially represented in the territory, information on the hazard and the exposure indicators (both in vector format) are jointly intersected providing information on the hazard for each indicator within the flooded areas. The other indicators, social and population vulnerability and business settings, are calculated using statistical data provided in Catalonia at the municipality level, this being the minimum available scale.

To evaluate exposure values for the marine flooding component, a buffer area of $100 \mathrm{~m}$ along the coast is considered. Since no map is available to provide information on the flooded area, the buffer is considered the maximum expected extent of the flood landwards of the beach. This buffer area is selected given the characteristics of this process in the Maresme coast (also applicable to most of the Mediterranean coast), so it should be adapted depending on the area to be analysed. In areas where marine flooding can extend in large, low-lying areas such as a typical main flood in the North Sea (see e.g. McRobie et al. 2005; Dawson et al. 2009), this can be substituted by the area of the flood extension.

It should be noted here that vulnerability associated with the exposure values is not considered in this analysis. Hence, only the presence of a set of different socio-economic aspects is taken into account.

In what follows, the methodology carried out to evaluate and classify each indicator aforementioned is presented.

\subsubsection{Land use $\left(e_{L U}\right)$}

The land-use exposure indicator measures the different types of land uses in the flood area. To assess it by means of the land cover map of Catalonia (Ibàñez and Burriel 2010), which provides detailed information in vector format, land uses have been reclassified into ten classes, covering the most representative uses for the study area (Table 2). For each class, a value from one to five has been assigned, depending on their relative importance. In this sense, the criteria to establish the values will be dependent on the orientation of the analysis and the purposes of coastal management. In this study, an anthropocentric perspective has been adopted, and thus, higher values were assigned to those land uses where flood damages affecting economic activities are reported (see Table 2). This indicator does not consider the physical vulnerability of the different land uses but reflects the exposed area and the associated importance value for each land use. 


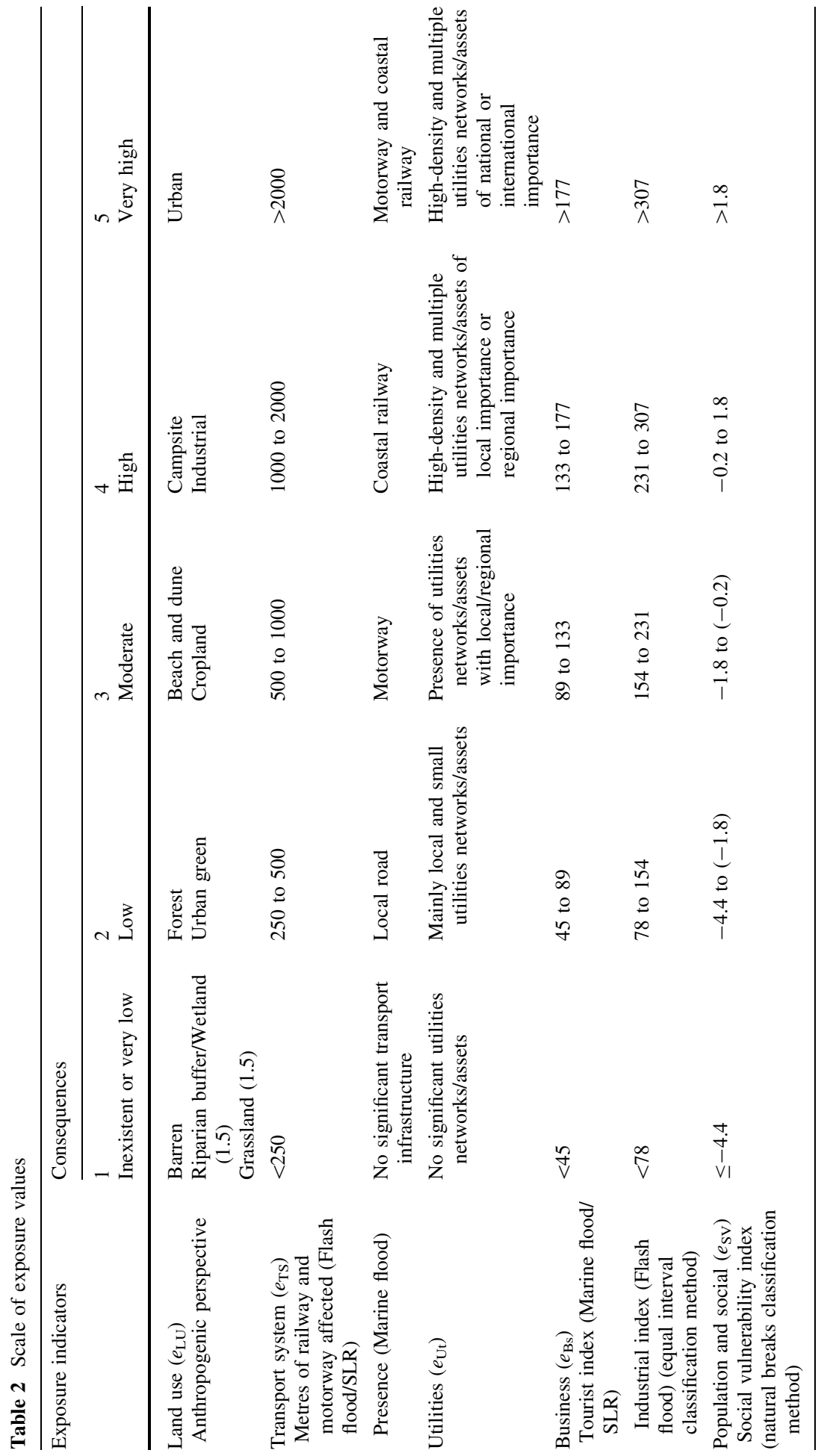




\subsubsection{Population and social vulnerability $\left(e_{S V}\right)$}

In order to measure intangible impacts to the flood-affected population, a social vulnerability index (SVI) has been applied. This index represents the relative vulnerability of various communities to long-term health impacts and financial recovery from a flood event (Viavattene et al. 2015). As there are no previous studies for the area to inform how the population may cope with flood events, characteristics and variables suggested by Tapsell et al. (2002) have been considered. The variables selected, listed below, accurately represent the socio-economic characteristics of the study area. Amongst the social variables, the long-term sick $(a)$, single parents $(b)$ and the elderly $(c)$ were taken into account. Financial deprivation variables were represented by unemployment $(d)$, overcrowded households $(f)$, non-car ownership $(g)$, and non-home ownership $(h)$. To create the social vulnerability index, each variable has to be standardised following different transformation methods to produce the minimum skewness kurtosis within their distributions (see Tapsell et al. 2002). As these authors suggest, the aggregation method adopted gives more importance to the social variables than to the financial deprivation variables. Equation 5 presents the aggregation method used:

$$
e_{\mathrm{SV}}=a+b+c+((d+f+g+h) * 0.25)
$$

An important consideration when applying the SVI is the level of data aggregation. For the Maresme case study, due to small municipality dimensions in terms of settlement and built-up areas, and the fact that this is a regional study, the most appropriate available data (IDESCAT 2014) are at the municipality level. This can be considered the minimum scale for obtaining SVI values. However, if data are available at smaller scales (e.g. census level), it should be implemented at this level as the extension of the flood plain is often narrow and short.

Since this study represents a regional assessment, the social vulnerability indicator $\left(e_{\mathrm{SV}}\right)$ value obtained for each municipality has been reclassified on a relative basis into five classes using the natural breaks method. This is considered an adequate method to identify groups with similar values, whilst maximising the differences between classes (see Table 2).

\subsubsection{Transport system $\left(e_{T s}\right)$}

Another key element when assessing the consequences of flood events is the disruption to the transport system. To obtain a representative indicator of the direct impact of flood events on this infrastructure, the total linear metres of railway and motorway have been considered for the components where the flooded area is known, such as for flash flood and SLR-induced inundation. The total value is ranked into five classes considering that damages will be higher when a greater length of total transport system at regional scale has become exposed. For the marine flooding component, where the total flooded area is not known, the indicator is built considering the presence or absence of different transport systems within the buffer area. This is ranked into five classes, taking into account the relative importance of each transport infrastructure to the overall system and the probable systemic impacts resulting from their disruption (see Table 2). 


\subsubsection{Critical infrastructure $\left(e_{C I}\right)$}

This component assesses the presence of utilities providing essential services that flooding can affect, interrupt, or cause a cease in operation with serious consequences for the community, both inside and outside of the affected area. The presence of critical infrastructure in the flood area has been identified with the information provided in the land-use map. Once identified, these infrastructures were classified on a scale from one to five according to their relative importance at different spatial levels in the community (see Table 2).

\subsubsection{Business settings $\left(e_{B s}\right)$}

To assess the impact of coastal floods on business activity, two indices were selected in this case. For marine processes (such as marine flood and SLR-induced inundation) on the coastal fringe, tourism is the most representative economic sector involved. To obtain a representative value of this activity, a tourist index developed by the Spanish bank La Caixa (2013) was used. This is a relative index based on the tax rate (Business Activities Tax), which takes into account the number of rooms and the annual occupancy and category of tourist establishments. The index value is the percentage share of each municipality relative to the entire nation, which can be expressed as:

$$
\text { Tourist index }=\frac{\text { Municipality tax rate }}{\text { Total taxes rates in Spain }} \times 100,000
$$

Damages caused by flash floods can be found inland where other businesses may be located. An industrial index also developed by La Caixa (2013) was used as a good representation in the assessment of flash flood consequences to business activity. This index is based on tax revenues corresponding to industrial activities and reflects the relative weight of industry in each municipality with respect to all of Spain as follows:

$$
\text { Industrial index }=\frac{\text { Municipality tax rate }}{\text { Total taxes rates in Spain }} \times 100,000
$$

Both indices have been ranked on a relative basis into five categories by applying an equal intervals method.

\section{Results}

\subsection{Flash flood}

Figure 3 shows the FFPI' along the Maresme coast, integrated at the sub-basin level. These results indicate that for the same region there are differences in the level of susceptibility to the effects of flash flooding, mainly due to geomorphological characteristics such as the slope and the type of soil. As a result, this first step has allowed for the identification of the most hazardous areas along the coast.

In addition, the potential flooding areas identified by the Catalan Water Agency (Generalitat de Catalunya 2015) in order to implement the EU Floods Directive (Directive 2007/60/EC) are also presented in Fig. 3. These areas were identified by combining geomorphological studies based on visual analyses (topography and morphology), flooding 
studies, aerial photographs, and field visits. This information suggests that there is a strong correlation between the largest flood areas and medium and high FFPI' levels, which allows for a validation of this index as a first approach for identifying areas prone to flash floods.

In the second step, those sub-basins likely to be affected by flash flooding with medium and high FFPI' levels were chosen to undertake a detailed flash flood assessment. Data on the sub-basins prone to flash flooding were obtained from the Catalan Water Agency (Generalitat de Catalunya 2015) which uses hydrologic and hydraulic studies to determine the flood area, and variables such as the flood depth or flood velocity associated with three return periods. In this case, the flood depth information for a return period of 100 years has been used. In Fig. 4, flash flood components are represented along the study area by their extension and ranked into a flash flood hazard indicator. If areas are classified in terms of the average hazard intensity (flood depth values), the most hazardous area is located in Sant Pol de Mar (12). The second most hazardous area is Argentona stream with the

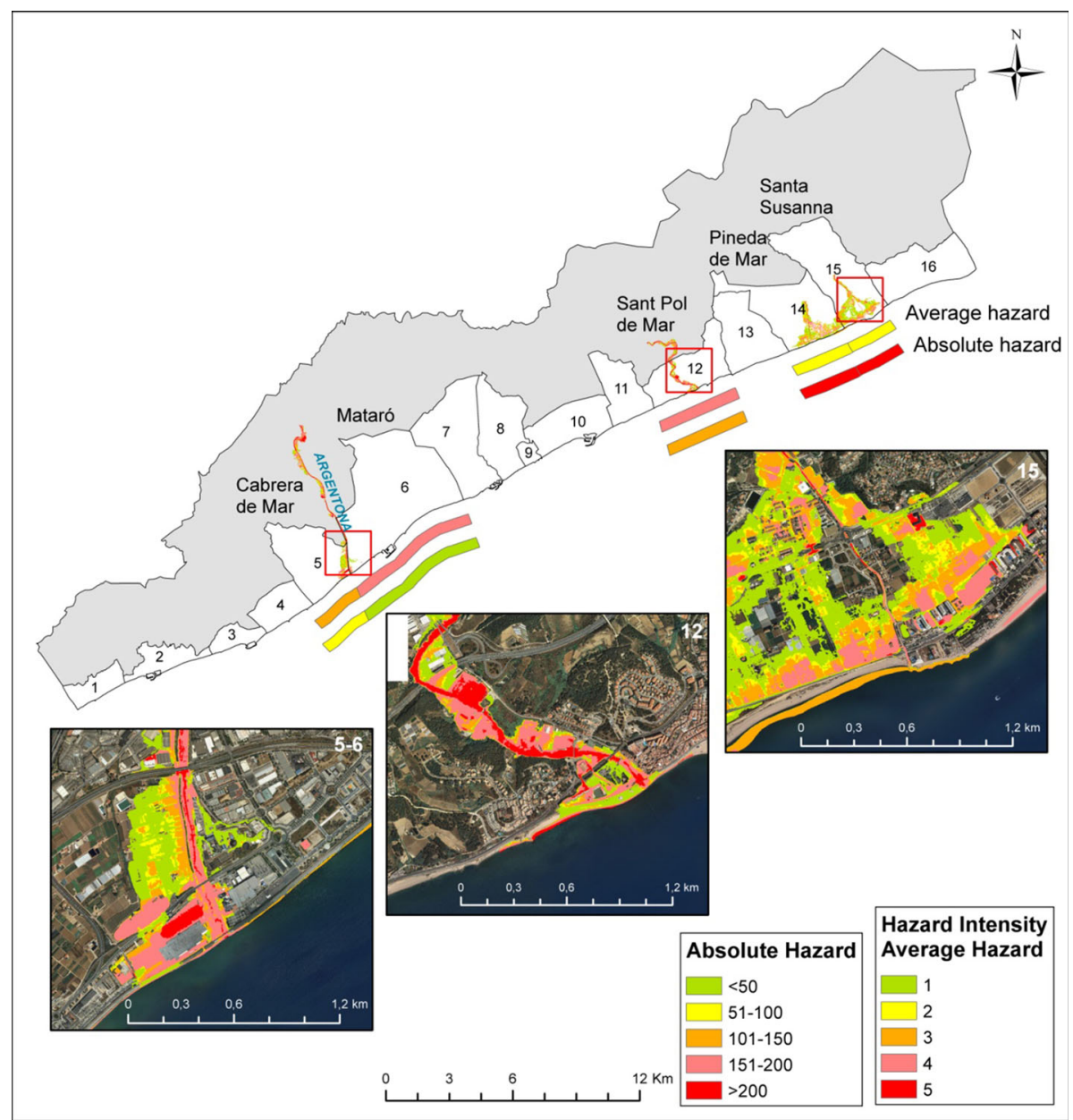

Fig. 4 Flash flood hazard for the most susceptible sub-basins in the Maresme region 


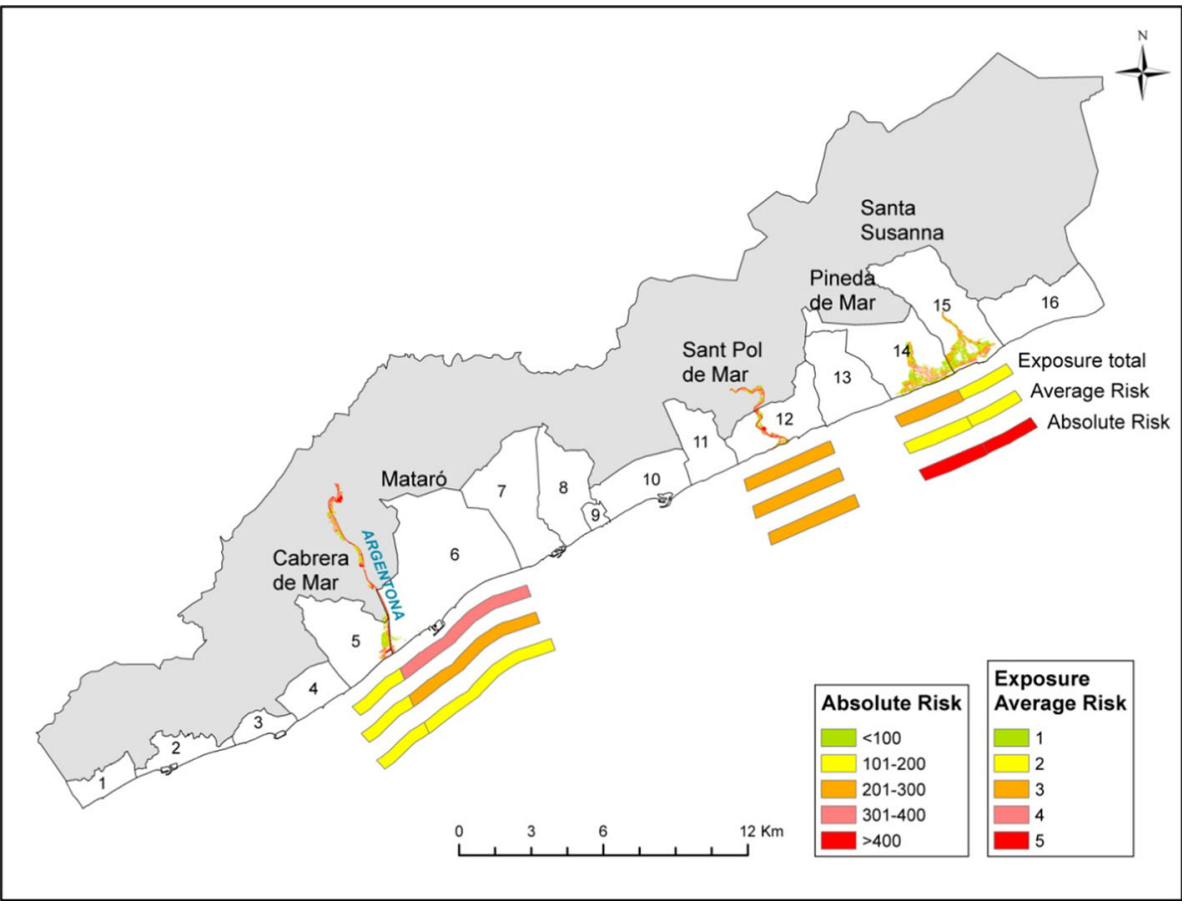

Fig. 5 Flash flood exposure and risk for the most susceptible sub-basin in the Maresme region

highest values in Mataró (6). When the hazard is evaluated in absolute terms, i.e. taking into account the total affected area, the most hazardous locations are Santa Susanna (15) and Pineda de Mar (14).

Obtained exposure indicators for the areas are representative of medium values (Fig. 5) with Mataró (6) showing the highest values. This is due to the existence of a differing number of assets with high relevance at local and regional level being affected (e.g. railway, road, factories and a water treatment plant) as well as the high values of social and population vulnerability to floods.

By combining hazard and exposure values, the average and absolute flood risk value obtained shows the municipalities of Mataró (6) and Sant Pol de Mar (12) as having the highest average risk values, whereas Santa Susanna (15) and Pineda de Mar (14) show the highest absolute risk.

\subsection{Marine flood}

Marine flood hazard intensity is presented in Fig. 6 over the 46 sectors of about one $\mathrm{km}$ in length along the coastline within the buffer area considered. The results show that the study area can generally be considered to have a low level of marine flood hazard. There are exceptions to this in a few sectors, where the hazard intensity is high due to the combination of both large runup values and low topographic levels. Therefore, these sectors represent the most highly susceptible areas to be affected by marine storm-induced runup. However, since the goal of this study is to undertake a comparative analysis amongst floods, the results at the sector level have been integrated at the municipality level. 


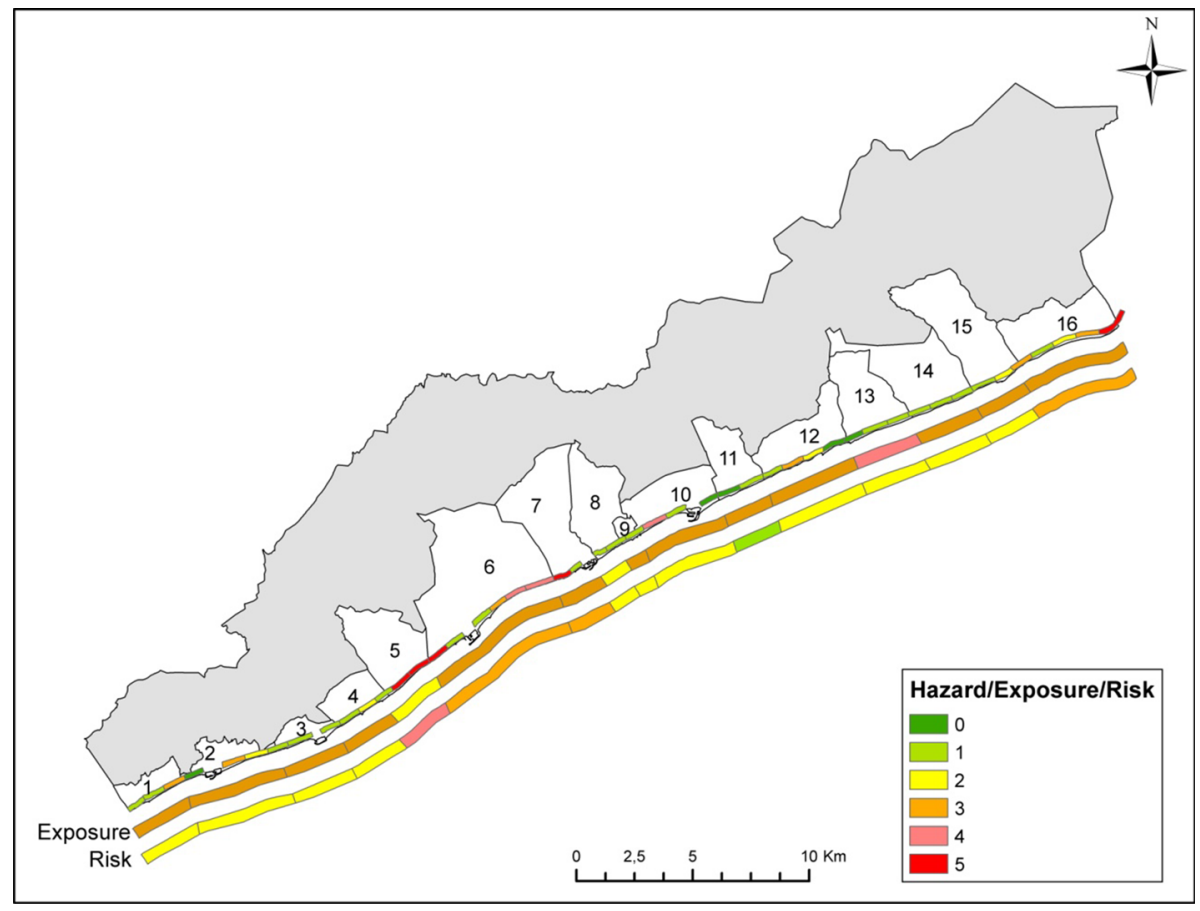

Fig. 6 Marine flood hazard intensity, exposure, and risk along the Maresme coast

Nevertheless, it should be noted that due to the short length of these sectors and marine flooding scope, important hot spots can be hidden at this level.

In Fig. 6, exposure and risk indicators at the municipality level are also shown. However, in order to obtain a detailed representation of the various exposure values considered, in Fig. 7 each individual exposure indicator and the total exposure indicator are shown. The results indicate that although the total values of the exposure index seem to be quite homogenous for all of the municipalities, differences can be observed when exposure values are evaluated individually, as is the case with the social vulnerability indicator $\left(e_{\mathrm{SV}}\right)$ and the business settings indicator $\left(e_{\mathrm{BS}}\right)$.

Risk values indicate a low risk of marine flooding. However, municipalities such as Cabrera de Mar (5), Mataró (6), and Malgrat de Mar (16) are the municipalities of greatest risk within the study area.

\subsection{Inundation by sea level rise}

In Fig. 8, the SLR hazard is presented considering a RCP 8.5 and a high-end scenario within the study area. As can be observed, the extension of inundation is very small, since it can only be appreciated in the north where the low-lying area of the Tordera Delta (16) is located for the high-end scenario. With the exception of the Tordera delta, these results indicate the relatively low importance of SLR, in terms of inundation, due to the small flood-prone areas which are only restricted to beaches.

The largest inundated increase from scenario RCP 8.5 to high end occurs for the highest part of the territory. These require a longer time to be inundated, and as a consequence, 


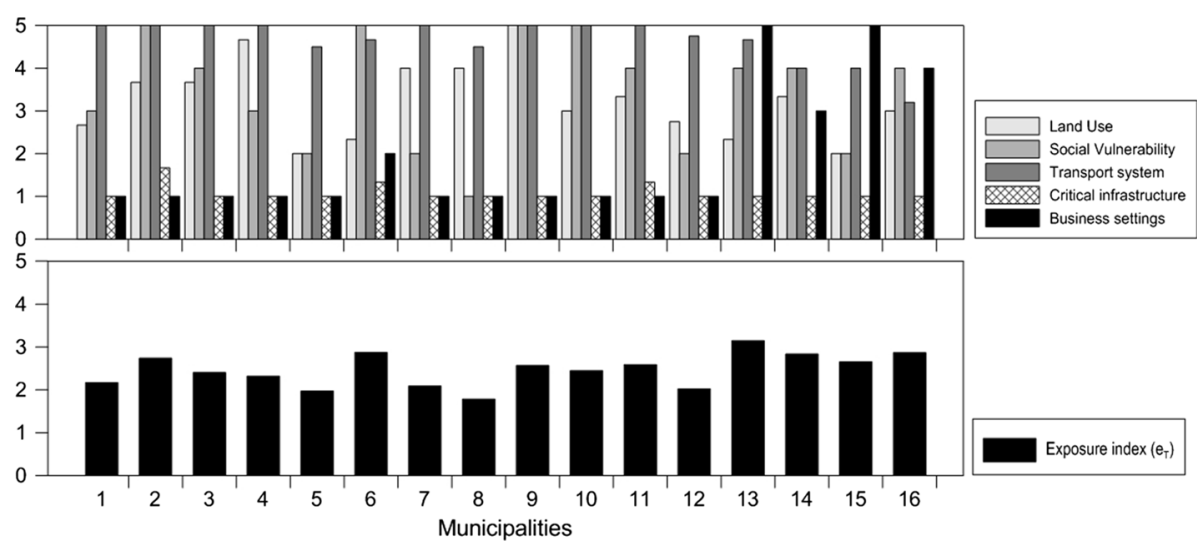

Fig. 7 Exposure values for marine flooding (within $100 \mathrm{~m}$ buffer) and total exposure index for the Maresme coastal municipalities

given the hazard intensity classification adopted, new areas are essentially of low risk (Fig. 9).

This highlights the geomorphological characteristics of the coastline, which can be typified as having steep profile slopes (with the exception being the low-lying area of the Tordera delta). In Fig. 9, the total area affected considering each scenario over time and their corresponding hazard intensity are presented. Moreover, Fig. 9 presents the total flooded area by 2100 for each municipality and scenario. Results emphasise the importance of the SLR component in the north of the region for the municipality of Malgrat de Mar (16).

\subsection{Integrated risk}

Figure 10 shows an integrated representation of flooding risk along the Maresme coast. It can be observed that the average risk magnitudes associated with each component are fairly similar amongst the municipalities, without highlighting any component, apart from local singularities. This homogenous pattern is due to both the spatial distribution of exposure values and hazard intensity.

Nevertheless, when the flood area is considered, specific locations of interest can be identified along the territory for each component. For instance, although the average risks associated with flash floods tend to be similar to other components, with respect to the affected flood areas, it can be viewed as an increased risk, especially within the municipalities of Pineda de Mar (14) and Santa Susanna (15). However, in the municipalities identified as vulnerable to flash floods, the risk associated with this component is higher than in the other municipalities.

Regarding SLR, this can be considered a low risk, with the exception being the consideration of a high-end scenario for the municipality of Malgrat de Mar (16). This municipality reflects a singularity due to the flood plain area of the Tordera Delta. Thus, it is in this municipality that SLR represents the most important flood component. However, these results can only be appreciated when an absolute risk is considered, as no differences are found between scenarios when an average risk is taken into account. This is because, although in the high-end scenario the exposure index is higher (the flood area is 


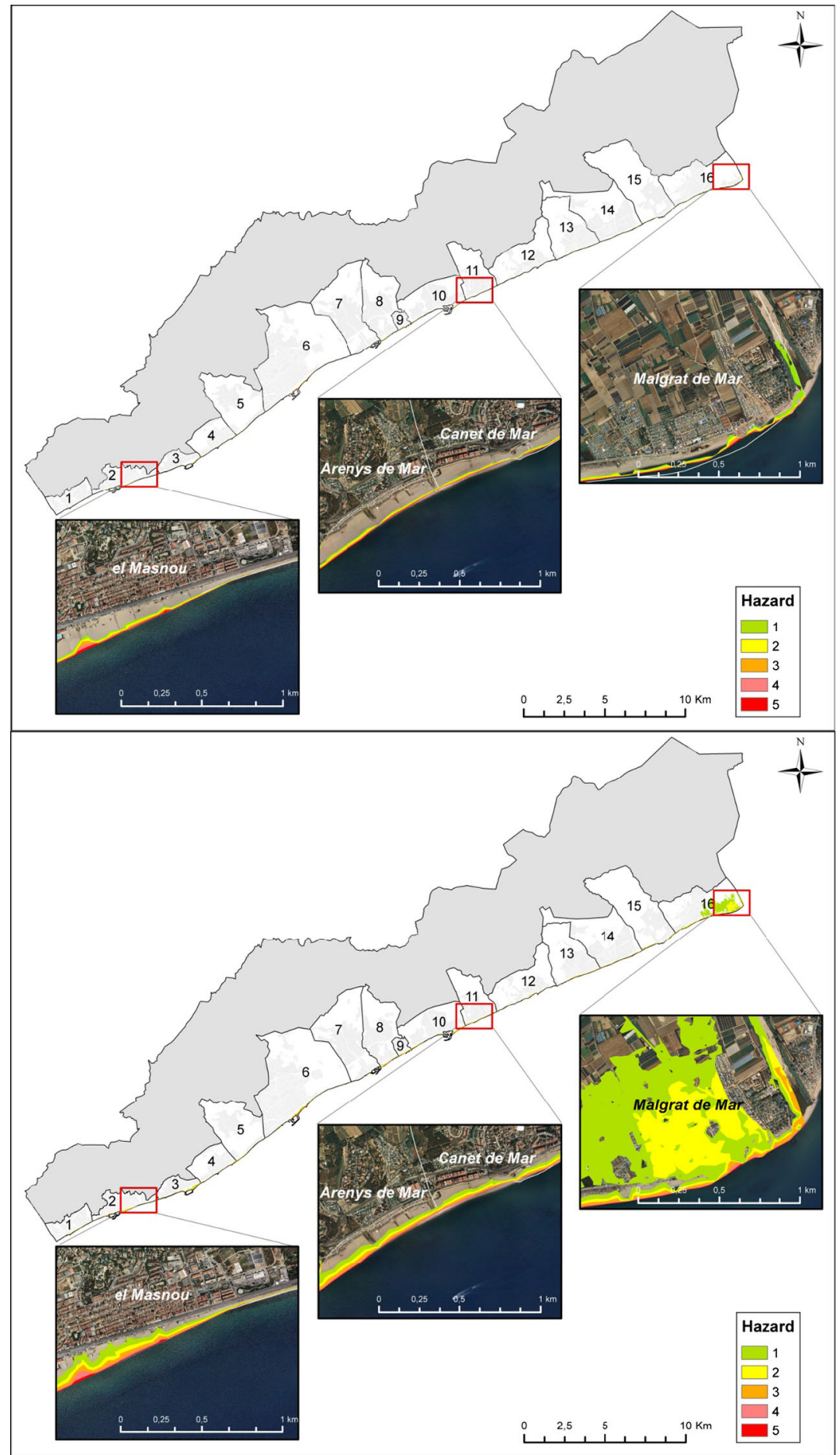

Fig. 8 SLR hazard intensity along the Maresme coast. RCP 8.5 (top) and H.E. scenario (bottom) 
(a)

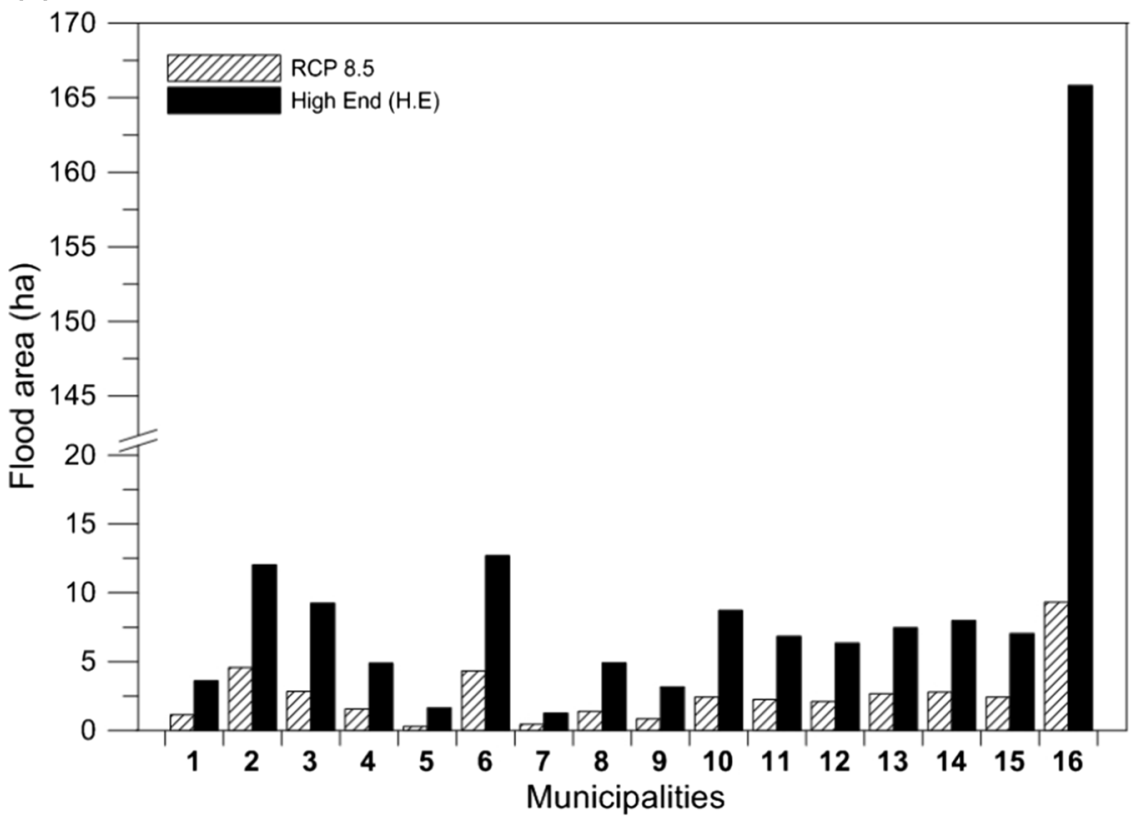

(b)

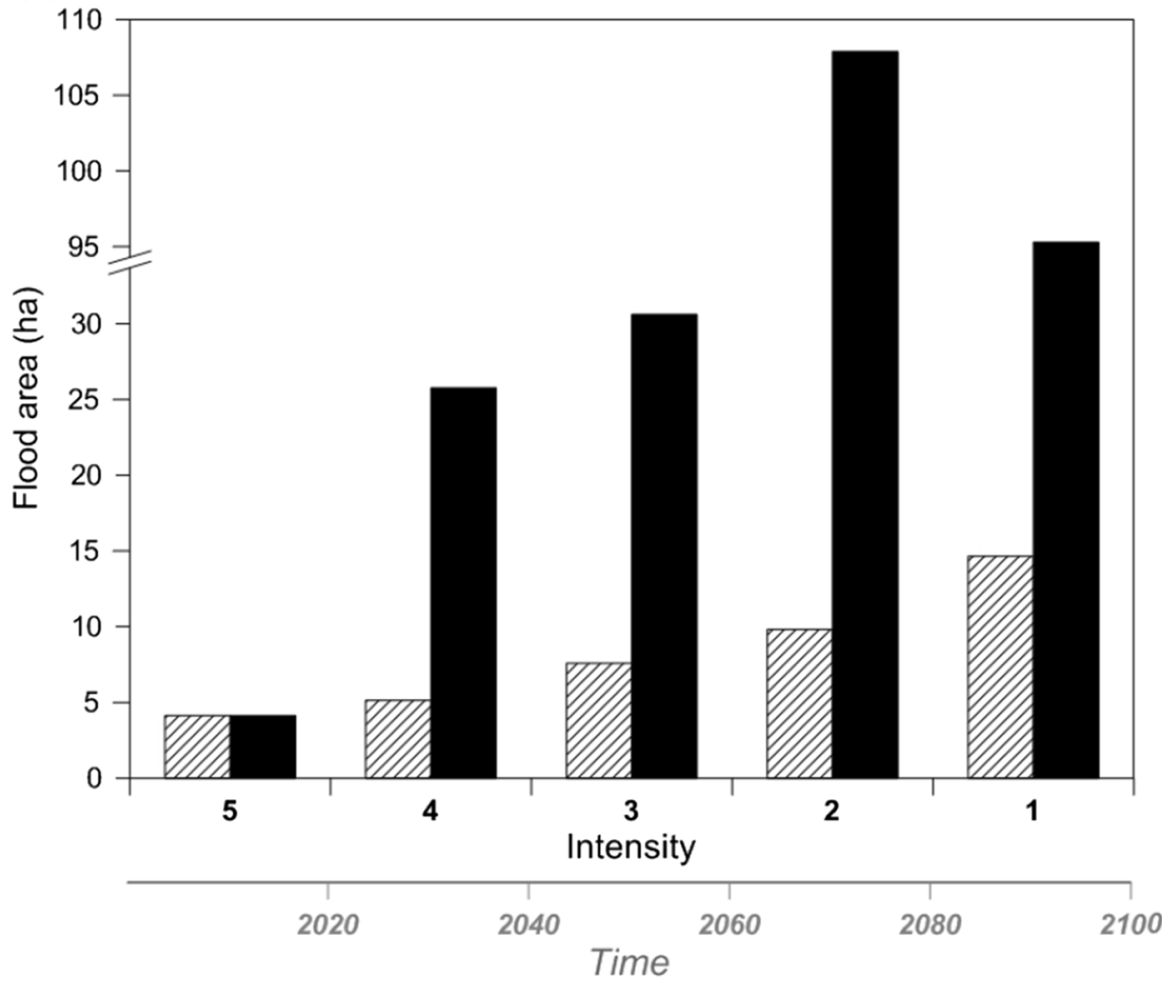


4Fig. 9 a Permanent inundated area at 2100 in the Maresme coastal municipalities due to different SLR scenarios. b Permanent incremental inundated area due to different SLR scenarios and the associated hazard intensity for the entire Maresme

(a)

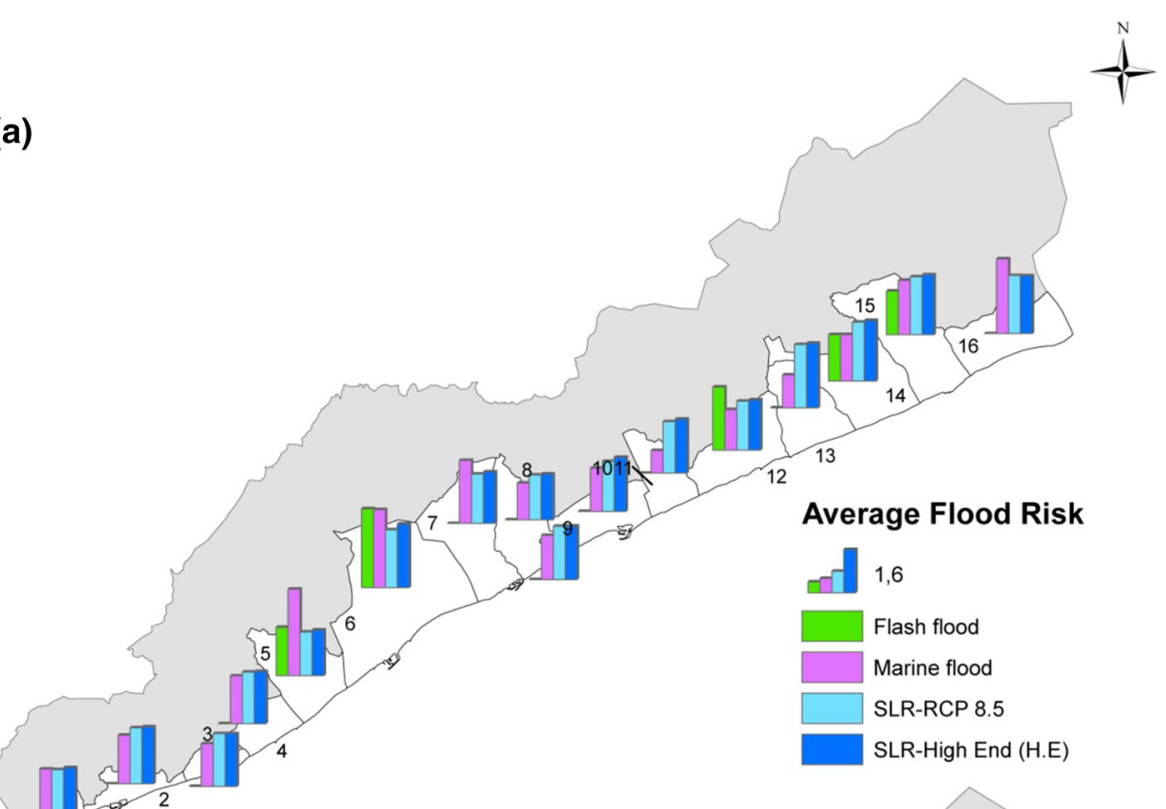

(b)

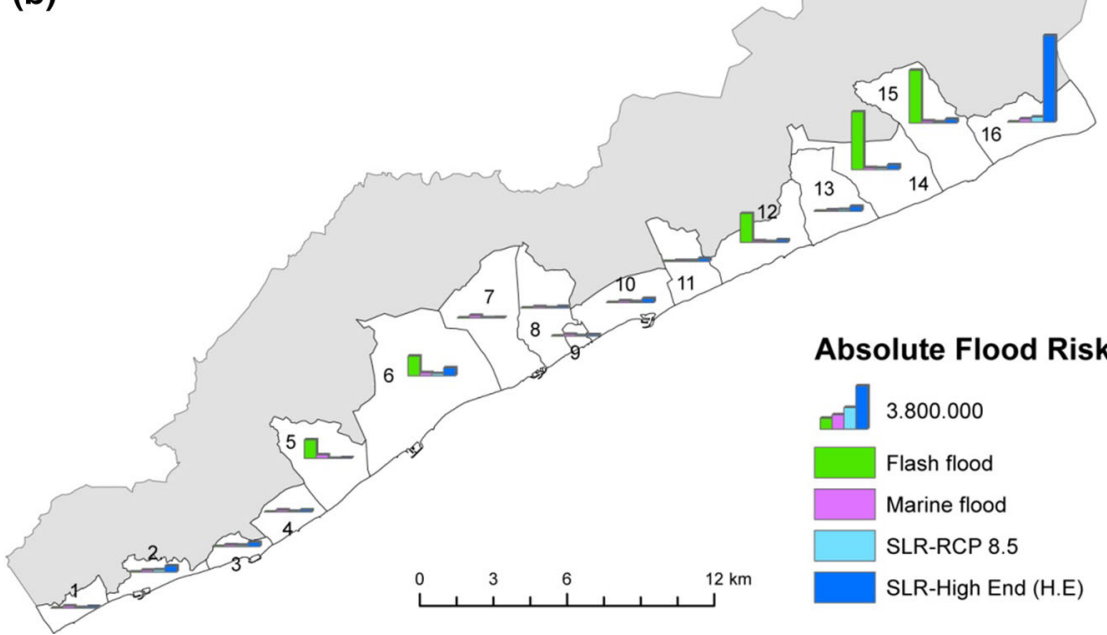

Fig. 10 Integrated flood risk components along the Maresme coastal municipalities (dimensionless). a Average flood risk (classified between 1 and 5). b Absolute flood risk 
significantly larger), the relative hazard intensity is much lower, considering the total flood area affected, and this results in a similar average risk for both scenarios.

Finally, regarding marine flood risks, obtained values indicate a uniform pattern along the coast with low absolute values and no particular municipality identified. However, it is important to bear in mind that as the values have been aggregated at the municipal level, (small-scale) areas can be found at the local level where the risks associated with marine storms are significantly high (Fig. 6).

\section{Discussion and conclusions}

In this work, a coastal flood risk assessment has been presented at a regional scale with the use of indicators that have allowed for the characterisation of different coastal flood hazards and their consequences. The adopted approach estimates the risk by combining hazard and values at exposure, and in consequence, it should be equivalent to the maximum potential damages which may occur if an area is inundated (Messner and Meyer 2006). This approach is acceptable at mesoscale (regional) level and when the objective of the analysis is to identify the most sensitive areas to considered hazards. A similar approach to assess flood risk at regional level in the Emilia-Romagna (Italy) can be seen in Perini et al. (2016). In absence of depth-damage curves, they assessed the damage using land-use maps and assigned the vulnerability of each type as a function of their characteristics. Thus, they associated the highest vulnerability (and damage) to infrastructures such as urban areas and industrial zones, whereas areas without human occupation, such as beaches, were considered less exposed and given the lowest value. Exposed values in inundated urban areas are considered to be fully affected (damaged) without considering the depth of inundation. This approach is also used by Rizzi et al. (2017) to develop a regional risk assessment.

On the other hand, if the analysis is carried out at local scale, or final decisions on specific protection and adaptation measures have to be taken, damage potential has to be converted to expected damages by introducing the susceptibility of elements at risk. This is done using relative damage functions which give the expected degree of damage, usually as a function of the inundation depth (e.g. Merz et al. 2007). In any case, both approaches can be considered complementary, i.e. to start with a regional scale analysis as the one presented here and, in those locations identified as high-risk areas, to launch a standard flood risk assessment with specific depth-damage curves. An example of this two-step approach is the Coastal Risk Assessment Framework adopted in the RISC-KIT project (Van Dongeren et al. 2014; Viavattene et al. 2015).

The proposed methodology analyses the different flood contributions in an uncoupled manner, i.e. by assessing the importance of each component individually. Within a regional flood risk analysis framework, this permits to identify their relative intensity along the territory, i.e. which are the most sensitive municipalities to each flood component. When comparing the magnitude of the different individual components, it has to be considered that, implicitly, it is assumed that the associated potential damage will be independent of the flood source. However, a comparison has been made between transient (associated with marine and flash floods) and permanent (associated with sea level rise) inundation components and the way they induce damage is different. In transient flood events, velocity is an important variable, whereas final inundation depth is the only variable to be considered in permanent flooding. In spite of this, this approach is valid to obtain a first estimation of 
the relative potential importance of each component. In this sense, this type of comparison can be useful for a multi-component risk perception analysis (e.g. Harvatt et al. 2011).

Obtained results characterise the Maresme coast as an area with a relatively low risk of being affected by floods. However, some hot spots are found along its coastline, where risk levels significantly increase with respect to adjacent areas. These hot spots are located in different areas depending on the flood component to be considered. Thus, the area has a very low sensitivity to SLR due to its topography characterised by high and steep beaches that protect the hinterland against long-term permanent inundation. As a consequence, the SLR-induced flood risk is very low in the entire area with the exception of the Tordera delta, which is the only low-lying coastal area along the Maresme. This concentration of atrisk SLR areas in few locations associated with river deltas and coastal plains is typical of the entire Catalan coast (Oltra et al. 2011) as well in most of Mediterranean countries (e.g. Bondesan et al. 1995; Paskoff 2004; Snoussi et al. 2009). Even in this case, the flood risk is only significant under the high-end scenario because despite being the lowest area in the region, it is higher than other low-lying plains in Catalonia, which are formed by finer sediments and have lower elevations (e.g. Alvarado-Aguilar et al. 2012).

With regard to marine floods, the spatial distribution of the associated integrated risk is quite homogeneous along the region which reflects both the general beach morphology and the nearly alongshore uniform distribution of values at exposure. In this case, hot spots are essentially controlled at the small spatial scale. As in most of the Mediterranean coast, the water level during coastal storms is mainly controlled by wave-induced runup (Mendoza and Jiménez 2009; Armaroli et al. 2012; Gervais et al. 2012). Due to this, spatial variations in flood occurrence will mainly be controlled by variations in beach slope affecting runup magnitude and in beach/dune elevation, which determines how much floodwater volume can enter to the hinterland. It has to be highlighted that although storm-induced water level is much higher than SLR the extension of the flood-prone area will be much smaller. This is due to the fact that this is a transient flood event with a limited floodwater volume. This difference means that the use of the bathtub approach to delineate the storm-induced floodprone area will likely overestimate the magnitude of the flood event, especially in lowlying areas. To overcome this, a coastal buffer has been defined behind the beach which indicates the area usually exposed to this kind of event (see also Ferreira et al. 2016).

Finally, when present, flash floods have been identified as the flood component inducing the highest risk within the region. This is consistent with the analysis of Barredo (2007) of major flood disasters in Europe, where major means the number of registered casualties is greater than 70 and/or the direct damage is larger than $0.005 \%$ of EU GDP in the year of the disaster. In the aforementioned study, all the events classified as major disasters occurring in Spain are flash floods. Moreover, the Maresme study area has been identified as one of the most affected regions along the Catalan coast by this type of flood (Llasat et al. 2010a, b). The reason for the high risk associated with flash floods is because, in addition to their probability of occurrence, they occur in ephemeral river courses that usually cross urban areas, i.e. main villages in each municipality. Due to this, values at exposure are extremely high and, as a consequence, the corresponding risk is also very high (e.g. Vinet 2008). This is also common for most of the Mediterranean coastal zone (Ruin et al. 2008; Llasat et al. 2010a, b; Faccini et al. 2015).

In spite of the dominance of flash floods in those locations where they are present, it has to be stressed that this and the marine flood components are determined in terms of an event associated with a given probability of occurrence. Thus, some exceptional situations may occur, usually associated with very low probability events, where this rule is inverted. An example of this was the impact of the Xynthia storm in France, during which a much 
larger than expected number of casualties occurred, and the incurred damage exceeded those induced by very large flash flood events (e.g. Vinet et al. 2012).

When analysing the obtained results, it can be concluded that the proposed multicomponent flood risk assessment methodology is able to identify sensitive management units (municipalities) to each flood component at regional scale. Although the identified atrisk locations need further detailed small-scale risk assessment, this would indicate the need for a differentiated flood risk management along the Maresme coast.

Acknowledgements This work has been undertaken in the framework of the PaiRisClima and RISC-KIT research projects, funded by the Spanish Ministry of Economy and Competitiveness (CGL2014-55387-R) and the European Union (Grant No. 603458), respectively. The lead author was supported by a Ph.D. grant from the Ministry of Economy and Competitiveness of the Government of Spain. The authors would like to give additional thanks to Puertos del Estado of the Spanish Ministry of Public Works for supplying wave data.

Open Access This article is distributed under the terms of the Creative Commons Attribution 4.0 International License (http://creativecommons.org/licenses/by/4.0/), which permits unrestricted use, distribution, and reproduction in any medium, provided you give appropriate credit to the original author(s) and the source, provide a link to the Creative Commons license, and indicate if changes were made.

\section{References}

Alvarado-Aguilar D, Jiménez JA, Nicholls RJ (2012) Flood hazard and damage assessment in the Ebro Delta (NW Mediterranean) to relative sea level rise. Nat Hazards 62:1301-1321. doi:10.1007/s11069012-0149-x

Anselme B, Durand P, Thomas YF, Nicolae-Lerma A (2011) Storm extreme levels and coastal flood hazards: a parametric approach on the French coast of Langudoc (district of Leucate). C R Geosci 343:677-690

Armaroli C, Ciavola P, Perini L, Calabrese L, Lorito S, Valentini A, Masina M (2012) Critical storm thresholds for significant morphological changes and damage along the Emilia-Romagna coastline, Italy. Geomorphology 143:34-51. doi:10.1016/j.geomorph.2011.09.006

Balica SF, Wright NG, van der Meulen F (2012) A flood vulnerability index for coastal cities and its use in assessing climate change impacts. Nat Hazards 64:73-105. doi:10.1007/s11069-012-0234-1

Barnolas M, Llasat MC (2007) A flood geodatabase and its climatological applications: the case of Catalonia for the last century. Nat Hazards Earth Syst 7:271-281. doi:10.5194/nhess-7-271-2007

Barredo JI (2007) Major flood disasters in Europe: 1950-2005. Nat Hazards 42:125-148. doi:10.1007/ s11069-006-9065-2

Benavente J, Del Rio L, Gracia FJ, Martinez-Del-Pozo JA (2006) Coastal flooding hazard related to storms and coastal evolution in Valdelagrana spit (Cadiz Bay Natural Park, SW Spain). Cont Shelf Res 26:1061-1076. doi:10.1016/j.csr.2005.12.015

Birkmann J (2007) Risk and vulnerability indicators at different scales: applicability, usefulness and policy implications. Environ Hazards 7:20-31. doi:10.1016/j.envhaz.2007.04.002

Bondesan M, Castiglioni GB, Elmis C, Gabbianellis G, Marocco R, Pirazzoli PA, Tomasin A (1995) Coastal areas at risk from storm surges and sea-level rise in northeastern Italy. J Coast Res 11:1354-1379

Bosom E, Jiménez JA (2011) Probabilistic coastal vulnerability assessment to storms at regional scaleapplication to Catalan beaches (NW Mediterranean). Nat Hazard Earth Syst 11:475-484. doi:10.5194/ nhess-11-475-2011

Broxton PD, Zeng X, Scheftic W, Troch PA (2014) A MODIS-based $1 \mathrm{~km}$ Maximum green vegetation fraction dataset. J Appl Meteorol Clim 53:1996-2004. doi:10.1175/JAMC-D-13-0356.1

Bryan B, Harvey N, Belperio T, Bourman B (2001) Distributed process modeling for regional assessment of coastal vulnerability to sea-level rise. Environ Model Assess 6:57-65. doi:10.1023/A:1011515213106

Camarasa-Belmonte AM, Soriano-García J (2012) Flood risk assessment and mapping in peri-urban Mediterranean environments using hydrogeomorphology. Application to ephemeral streams in the Valencia region (Eastern Spain). Landsc Urban Plan 104:189-200. doi:10.1016/j.landurbplan.2011.10. 009 
Camarasa-Belmonte AM, López-García MJ, Soriano-García J (2011) Mapping temporally-variable exposure to flooding in small Mediterranean basins using land-use indicators. Appl Geogr 31:136-145. doi:10.1016/j.apgeog.2010.03.003

Ceru J (2012) The flash flood potential index for Pennsylvania. In: 2012 ESRI federal GIS conference. http:// proceedings.esri.com/library/userconf/feduc12/papers/user/JoeCeru.pdf

Creach A, Pardo S, Guillotreau P, Mercier D (2015) The use of a micro-scale index to identify potential death risk areas due to coastal flood surges: lessons from storm Xynthia on the French Atlantic coast. Nat Hazards 77:1679-1710. doi:10.1007/s11069-015-1669-y

Dawson RJ, Dickson ME, Nicholls RJ, Hall JW, Walkden MJA, Stansby PK, Mokrech M, Richards J, Zhou J, Milligan J, Jordan A, Pearson S, Rees J, Bates PD, Koukoulas S, Watkinson AR (2009) Integrated analysis of risks of coastal flooding and cliff erosion under scenarios of long term change. Clim Change 95:249-288. doi:10.1007/s10584-008-9532-8

de Moel H, Jongman B, Kreibich H, Merz B, Penning-Rowsell E, Ward PJ (2015) Flood risk assessments at different spatial scales. Mitig Adapt Strateg Glob Change 20:865-890. doi:10.1007/s11027-015-9654$\mathrm{z}$

De Pippo T, Donadio C, Penneta M, Petrosino C, Terlizzi F, Valente A (2008) Coastal hazard assessment and mapping in Northern Campania, Italy. Geomorphology 97:451-466. doi:10.1016/j.geomorph. 2007.08.015

European Commission (EC) (2007) Directive 2007/60/EC of the European Parliament and of the Council of 23 October 2007 on the assessment and management of flood risks. Off J L 288:27-34

European Commission (EC) (2015) European Soil Data Centre, ESDAC. https://esdac.jrc.ec.europa.eu/ resource-type/datasets. Accessed 10 May 2015

European Environment Agency (EEA) (2006) The changing faces of Europe's coastal areas. Report No 6, Copenhagen

European Environment Agency (EEA) (2013a) Balancing the future of Europe's coasts-knowledge base for integrated management. Report No 12. Copenhagen. doi:10.2800/99116

European Environment Agency (EEA) (2013b) Late lessons from early warnings: science, precaution, innovation. Floods: lessons about early warning systems. Report No 1, Copenhagen, pp 347-368. doi: $10.2800 / 73322$

European Insurance and Reinsurance Federation (CEA) (2007) Reducing the social and economic impact of climate change and natural catastrophes insurance solutions and public-private partnerships. CEA, Brussels

Evans E, Ashley R, Hall JW, Penning-Rowsell E, Sayers P, Thorne C, Watkinson A (2004) Foresight future flooding: scientific summary: volume I-future risks and their drivers. Office of Science and Technology, London

Faccini F, Luino F, Sacchini A, Turconi L (2015) Flash flood events and urban development in Genoa (Italy): lost in translation. In: Lollino G, Manconi A, Guzzetti F, Culshaw M, Bobrowsky P, Luino F (eds) Engineering geology for society and territory, vol 5. Springer, pp 797-801

Ferreira O, Viavattene C, Jiménez JA, Bole A, Plomaritis T, Costas S, Smets S (2016) CRAF phase 1, a framework to identify coastal hotspots to storm impacts. In: FLOODrisk 2016-3rd European conference on flood risk management, E3S web of conferences 7, 11008. doi:10.1051/e3sconf/ 20160711008

Gallien TW, Schubert JE, Sanders BF (2011) Predicting tidal flooding of urbanized embayments: a modeling framework and data requirements. Coast Eng 58:567-577. doi:10.1016/j.coastaleng.2011.01.011

Gaume E, Bain V, Bernardara P, Newinger O, Barbuc M, Bateman A, Blaskovicova L, Blöschl G, Borga M, Dumitrescu A, Daliakopoulos I, Garcia J, Irimescu A, Kohnova S, Koutroulis A, Marchi L, Matreata S, Medina V, Preciso E, Sempere-Torres D, Stancalie G, Szolgay J, Tsanis I, Velasco D, Viglione A (2009) A compilation of data on European flash floods. J Hydrol 367:70-78. doi:10.1016/j.jhydrol. 2008.12.028

Generalitat de Catalunya (2015) Agència Catalana de l'Aigua (ACA). http://aca-web.gencat.cat/aca/ appmanager/aca/aca/ Accessed 10 Jan 2015

Gervais M, Balouin Y, Belon R (2012) Morphological response and coastal dynamics associated with major storm events along the Gulf of Lions coastline, France. Geomorphology 143:69-80. doi:10.1016/j. geomorph.2011.07.035

Gornitz VM (1990) Vulnerability of the East Coast, U.S.A. to future sea level rise. J Coast Res 9:201-237

Gouldby B, Samuels P (2005) Language of risk, project definitions, FLOODsite project report T32-04-01, EU GOCE-CT- 2004-505420. http://www.floodsite.net/html/partner_area/project_docs/FLOODsite_ Language_of_Risk_v4_0_P1.pdf

Green PC, Viavattene C, Thompson P, Green C (2011) Guidance for assessing flood losses CONHAZ report (September), pp 1-86 
Guedes-Soares C, Weisse R, Carretero JC, Alvarez E (2002) A 40 years hindcast of wind, sea level and waves in european waters. In: Proceedings of the 21 st international conference on offshore mechanics and arctic engineering, pp 669-675

Hallegatte C, Nicholls Green RJ, Corfee-Morlot J (2013) Future flood losses in major coastal cities. Nat Clim Change 3:802-806

Harvatt J, Petts J, Chilvers J (2011) Understanding householder responses to natural hazards: flooding and sea-level rise comparisons. J Risk Res 14:63-83. doi:10.1080/13669877.2010.503935

Hinkel J, Jaeger C, Nicholls RJ, Lowe J, Renn O, Peijun S (2015) Sea-level rise scenarios and coastal risk management. Nat Clim Change 5:188-190. doi:10.1038/nclimate2505

Holdgate MW (1979) A perspective of environmental pollution. Cambridge University Press Cambridge, Cambridge

Ibàñez JJ, Burriel JA (2010) Mapa de cubiertas del suelo de Cataluña: características de la tercera edición y relación con SIOSE. Tecnol de La Inf Geogr La Inf Geogr Al Serv de Los Ciudad 3:179-198

ICGC (2015) Institut Cartografic i Geològic de Catalunya. Generalitat de Catalunya. www.icc.cat. Accessed 9 Feb 2015

IDESCAT (2014) Anuari Estadístic de Catalunya. Institut d'Estadística de Catalunya. Generalitat de Catalunya. www.idescat.cat. Accessed 15 Dec 2014

Instituto Nacional de Meteorología (INM) (2007) Estudio sobre precipitaciones máximas diarias y periodos de retorno para un conjunto de estaciones pluviométricas seleccionadas de España. CD

Insurance Compensation Consortium (2016). http://www.consorseguros.es/web/inicio Accessed 30 July 2016

IPCC (2015) Climate Change 2014: Synthesis report. Contribution of working group I,II and III to the fifth assessment report of the intergovernmental panel on climate change. IPCC, Geneva, Switzerland

Jiménez JA, Sancho-García A, Bosom E, Valdemoro HI, Guillén J (2012) Storm-induced damages along the Catalan coast (NW Mediterranean) during the period 1958-2008. Geomorphology 143-144:24-33. doi:10.1016/j.geomorph.2011.07.034

Jiménez JA, Armaroli C, Berenguer M, Bosom E, Ciavola P, Ferreira O, Plomaritis H, Roelvink D, Sanuy M, Sempere D (2015) Coastal hazard assessment module. RISC-KIT deliverable. D2.1. http://www. risckit.eu/np4/file/23/RISCKIT_D.2.1_Coastal_Hazard_Asssessment.pdf

Kappes MS, Keiler M, von Elverfeldt K, Glade T (2012) Challenges of analyzing multi-hazard risk: a review. Nat Hazards 64:1925-1958. doi:10.1007/s11069-012-0294-2

Kron W (2013) Coasts: the high-risk areas of the world. Nat Hazards 66:1363-1382. doi:10.1007/s11069012-0215-4

La Caixa (2013) Anuario Económico de España, Caja de Ahorros y Pensiones de Barcelona, Barcelona. www.anuarioeco.lacaixa.comunicacions.com/java/X?cgi=caixa.anuari99.util. ChangeLanguageandlang=esp. Accessed 2 Oct 2015

Llasat MC (2009) A press database on natural risks and its application in the study of floods in Northeastern Spain. Nat Hazards Earth Syst 2000:2049-2061

Llasat MC, Llasat-Botija M, Prat MA, Porcu F, Price C, Mugnai A, Lagouvardos K, Kotroni V, Katsanos D, Michaelides S, Yair Y (2010a) High-impact floods and flash floods in Mediterranean countries: the FLASH preliminary database. Adv Geosci 23:47-55

Llasat MC, Llasat-Botija M, Rodriguez A, Lindbergh S (2010b) Flash floods in Catalonia: a recurrent situation. Adv Geosci 26:105-111. doi:10.5194/adgeo-26-105-2010

Marchi L, Borga M, Preciso E, Gaume E (2010) Characterisation of selected extreme flash floods in Europe and implications for flood risk management. J Hydrol 394:118-133. doi:10.1016/j.jhydrol.2010.07.017

McLaughlin S, Cooper JAG (2010) A multi-scale coastal vulnerability index: a tool for coastal managers? Environ Hazards 9:233-248. doi:10.3763/ehaz.2010.0052

McLaughlin S, McKenna J, Cooper JAG (2002) Coastal Socio-economic data in coastal vulnerability indices: constraints and opportunities. J Coast Res 497:487-497

McRobie A, Spencer T, Gerritsen H (2005) The big flood: North sea storm surge. Philos Trans R Soc A 363:1263-1270. doi:10.1098/rsta.2005.1567

Mendoza ET, Jiménez J (2009) Regional vulnerability analysis of Catalan beaches to storms. Proc Inst Civil Eng Marit Eng 162:127-135

Merz B, Thieken A, Gocht M (2007) Flood risk mapping at the local scale: concepts and challenges. In: Begum S, Stive MJF, Hall JW (eds) Flood risk management in Europe. Advances in natural and technological hazards research, vol 25. Springer, Dordrecht, pp 231-251

Messner F, Meyer V (2006) Flood damage, vulnerability and risk perception-challenges for flood damage research. In: Schanze J, Zeman E, Marsalek J (eds) Flood risk management: hazards, vulnerability and mitigation measures, Springer, pp 149-167 
Messner F, Meyer V, Penning-Rowsell EC, Green C, Tunstall S, van der Veen A (2007) Evaluating flood damages: guidance and recommendations on principles and methods, FLOODsite project deliverable D9.1. Wallingford, FloodSite Consortium

Meyer V, Becker N, Markantonis V, Schwarze R, van den Bergh JCJM, Bouwer LM, Bubeck P, Ciavola P, Genovese E, Green C, Hallegatte S, Kreibich H, Lequeux Q, Logar I, Papyrakis E, Pfurtscheller C, Poussin J, Przylusky V, Thieken AH, Viavattene C (2013) Review article: assessing the cost of natural hazards-state of the art and knowledge gaps. Nat Hazard Earth Syst 13:1351-1373. doi:10.5194/nhess13-1351-2013

Narayan S, Nicholls RJ, Clarke D, Hanson S, Reeve D, Horrillo-Caraballo J, le Cozannet G, Hissel F, Kowalska B, Parda R, Willems P, Ohle N, Zanuttigh B, Losada I, Ge J, Trifonova E, Penning-Rowsell E, Vanderlinden JP (2014) The SPR systems model as a conceptual foundation for rapid integrated risk appraisals: lessons from Europe. Coast Eng 87:15-31. doi:10.1016/j.coastaleng.2013.10.021

Nicholls RJ, Hoozemans FMJ, Marchand M (1999) Increasing flood risk and wetland losses due to global sea-level rise: regional and global analyses. Glob Environ Change 9:S69-S87

Oltra A, Del Río L, Jiménez JA (2011) Sea level rise flood hazard mapping in the Catalan coast (NW Mediterranean). In: Proceedings of the CoastGIS 2011 Conference, vol. 4. pp 120-126

Paskoff RP (2004) Potential implications of sea-level rise for France. J Coast Res 20:424-434

Penning-Rowsell EC, Priest S, Parker D, Morris J, Tunstall S, Viavattene C, Chatterton J, Owen D (2013) Flood and coastal erosion risk management: a manual for economic appraisal. Routledge, London

Perini L, Calabrese L, Salerno G, Ciavola P, Armaroli C (2016) Evaluation of coastal vulnerability to flooding: comparison of two different methodologies adopted by the Emilia-Romagna region (Italy). Nat Hazards Earth Syst 16:181-194. doi:10.5194/nhess-16-181-2016

Poulter B, Halpin PN (2008) Raster modelling of coastal flooding from sea-level rise. Int J Geogr Inf Syst 22:167-182. doi:10.1080/13658810701371858

Pullen T, Allsop NWH, Bruce T, Kortenhaus A, Schüttrumpf H, van der Meer JW (2007) EurOtop. Wave overtopping of sea defences and related structures: assessment manual. http://www. overtoppingmanual.com/manual.html. Accessed 12 June 2015

Ratsimandresy AW, Sotillo MG, Carretero Albiach JC, Álvarez Fanjul E, Hajji H (2008) A 44-year highresolution ocean and atmospheric hindcast for the Mediterranean Basin developed within the HIPOCAS Project. Coast Eng 55:827-842

Rizzi J, Torresan S, Zabeo A, Critto A, Tosoni A, Tomasin A, Marcomini A (2017) Assessing storm surge risk under future sea-level rise scenarios: a case study in the North Adriatic coast. J Coast Conserv (in press). doi:10.1007/s11852-017-0517-5

Ruin I, Creutin JD, Anquetin S, Lutoff C (2008) Human exposure to flash floods-Relation between flood parameters and human vulnerability during a storm of September 2002 in Southern France. J Hydrol $361: 199-213$

Sala M (2003) Floods triggered by natural conditions and by human activities in a Mediterranean coastal environment. Geogr Ann Ser A Phys Geogr 85:301-312. doi:10.1111/j.0435-3676.2003.00207.x

Saurí-Pujol D, Roset-Pagès D, Ribas-Palom A, Pujol-Caussa P (2001) The "escalator effect" in flood policy: the case of the Costa Brava, Catalonia, Spain. Appl Geogr 21:127-143

Schanze J (2006) Flood risk management-a basic framework. In: Schanze J, Zeman E, Marsalek J (eds) Flood risk management: hazards, vulnerability and mitigation measures. NATO Science Series, vol 67. Springer, Dordrecht, pp 1-20

Smith G (2003) Flash flood potential: determining the hydrologic response of FFMP basins to heavy rain by analyzing their physiographic characteristics. A white paper available from the NWS Colorado Basin River Forecast Center. http://www.cbrfc.noaa.gov/papers/ffp_wpap.pdf

Snoussi M, Ouchani T, Khouakhi A, Niang-Diop I (2009) Impacts of sea-level rise on the Moroccan coastal zone: quantifying coastal erosion and flooding in the Tangier Bay. Geomorphology 107:32-40. doi:10. 1016/j.geomorph.2006.07.043

Stockdon HF, Holman RA, Howd PA, Sallenger AH (2006) Empirical parameterization of setup, swash, and runup. Coast Eng 53:573-588. doi:10.1016/j.coastaleng.2005.12.005

Tapsell SM, Penning-Rowsell EC, Tunstall SM, Wilson TL (2002) Vulnerability to flooding: health and social dimensions. Philos Trans R Soc Lond A 360:1511-1525. doi:10.1098/rsta.2002.1013

Tarolli P, Borga M, Morin E, Delrieu G (2012) Analysis of flash flood regimes in the North-Western and South-Eastern Mediterranean regions. Nat Hazards Earth Syst 12:1255-1265. doi:10.5194/nhess-121255-2012

UNISDR United Nations Office for Disaster Risk Reduction (2009) UNISDR terminology on disaster risk reduction. United Nations International Strategy for Disaster Reduction (UNISDR), Geneva. http:// www.unisdr.org/we/inform/terminology 
Van Dongeren A, Ciavola P, Viavattene C, De Kleermaeker S, Martinez G, Ferreira O, Costa C, McCall R (2014) RISC-KIT: resilience-increasing strategies for coasts-toolKIT. J Coast Res SI 70:366-371

Velasco M, Cabello A, Russo B (2015) Flood damage assessment in urban areas. Application to the Raval district of Barcelona using synthetic depth damage curves. Urban Water J. doi:10.1080/1573062X. 2014.994005

Viavattene C, Jiménez JA, Owen DJ, Priest S, Parker DJ, Micou AP, Ly S (2015) Coastal risk assessment framework tool: guidance document. RISC-KIT deliverable. D2.3. http://www.risckit.eu/np4/file/23/ RISC_KIT_D2.3_CRAF_Guidance_.pdf

Vinchon C, Aubie S, Balouin Y, Closset L, Garcin M, Idier D, Mallet C (2009) Anticipate response of climate change on coastal risks at regional scale in Aquitaine and Languedoc Roussillon (France). Ocean Coast Manag 52:47-56. doi:10.1016/j.ocecoaman.2008.09.011

Vinet F (2008) Geographical analysis of damage due to flash floods in southern France: the cases of 12-13 November 1999 and 8-9 September 2002. Appl Geogr 28:323-336

Vinet F, Lumbroso D, Defossez S, Boissier L (2012) A comparative analysis of the loss of life during two recent floods in France: the sea surge caused by the storm Xynthia and the flash flood in Var. Nat Hazards 61:1179-1201

Wang Y, Li Z, Tang Z, Zeng G (2011) A GIS-based spatial multi-criteria approach for flood risk assessment in the Dongting Lake region, Hunan, Central China. Water Resour Manag 25:3465-3484 